\title{
Ground-truthing Late Ordovician climate models using the paleobiogeography of graptolites
}

\author{
Thijs R. A. Vandenbroucke, ${ }^{1,2}$ Howard A. Armstrong, ${ }^{3}$ Mark Williams, ${ }^{2,4}$
}

Jan A. Zalasiewicz, ${ }^{2}$ and Koen Sabbe ${ }^{5}$

Received 1 December 2008; revised 18 June 2009; accepted 14 July 2009; published 20 October 2009.

[1] The $\delta^{18} \mathrm{O}$ records obtained from conodonts suggest that during the Mid-Ordovician, equatorial temperatures stabilized at close to the present day, a hypothesis broadly supported by published climate models. However, the degree to which equatorial temperatures represent global climate state and varied between different climatic modes (greenhouse/icehouse, interglacial/glacial) and to what extent Ordovician $\delta^{18} \mathrm{O}$ and climate models truly reflect the global climate remain to be tested. Here we present paleobiogeographical data for the planktonic graptolites, from the gracilis time slice (i.e., early Sandbian Stage) that just postdates the postulated onset of climate stabilization. TWINSPAN analysis and constrained seriation provide robust ecological groupings in paleobiogeographical presence/absence data. The highest-level groups reflect tropical-subtropical assemblages and a high-southerly latitude assemblage. Constrained seriation defines latitude-distinct biotopes that are considered equivalent to modern zooplanktonic provinces. The distribution pattern of graptolite biotopes in the gracilis time slice show (1) that models explaining local graptolite ecological assemblages using lateral differentiation (e.g., upwelling) are to be favored above those using depth stratification and (2) a steep faunal gradient from equator to pole, which is typical of a cool, nongreenhouse world and comparable to the modern situation. We therefore broadly support the climate stabilization hypothesis. Paradoxically the climate of the early Late Ordovician appears similar to that of the present day despite the higher atmospheric $p \mathrm{CO}_{2}$ levels. Graptolite species were indicative of temperature-controlled ocean water masses, in much the same way as the modern zooplankton.

Citation: Vandenbroucke, T. R. A., H. A. Armstrong, M. Williams, J. A. Zalasiewicz, and K. Sabbe (2009), Ground-truthing Late Ordovician climate models using the paleobiogeography of graptolites, Paleoceanography, 24, PA4202, doi:10.1029/2008PA001720.

\section{Introduction}

[2] It is widely held that throughout the Phanerozoic the Earth experienced prolonged periods of greenhouse climate, punctuated by at least three severe glaciations. Much research effort has focused on the glaciations, in part because of their unique records and links with global mass extinctions, but conditions during the "background" greenhouse mode are less well known. The Ordovician Period has long been considered a supergreenhouse state. For example, marine $\delta^{18} \mathrm{O}_{\text {carb values from whole rock and brachiopods }}$ for the Ordovician range from $-2 \%$ to $-10 \%$ [Shields et $a l ., 2003$ ] and, assuming a present-day value for seawater $\left(\delta^{18} \mathrm{O}_{\mathrm{sw}} \sim-1 \%\right.$ ), the calculated seawater temperature in the tropics is as high as an improbable $70^{\circ} \mathrm{C}$ in the Early Ordovician [Shields et al., 2003; Trotter et al., 2008]. This has led to a hypothesis of changing isotopic values of

\footnotetext{
${ }^{1}$ Research Foundation-Flanders, Research Unit Palaeontology, Department of Geology and Soil Sciences, Ghent University, Ghent, Belgium.

${ }^{2}$ Department of Geology, University of Leicester, Leicester, UK.

${ }^{3}$ Palaeozoic Environments Group, Department of Earth Sciences, Durham University, Durham, UK.

${ }^{4}$ British Geological Survey, Keyworth, UK.

${ }^{5}$ Protistology and Aquatic Ecology, Department of Biology, Ghent University, Ghent, Belgium.
}

Copyright 2009 by the American Geophysical Union. 0883-8305/09/2008PA001720\$12.00 seawater through time [Shields et al., 2003]. A radically different view has recently emerged from $\delta^{18} \mathrm{O}$ records obtained from conodont bioapatite [Trotter et al., 2008]. For the equatorial latitudes these show (1) a steady cooling trend through the Early Ordovician reaching the range of modern equatorial temperatures by the Mid-Ordovician and (2) a significant decline in tropical temperatures during the Hirnantian glaciation.

[3] The degree to which tropical temperatures vary between different climate modes (greenhouse/icehouse, interglacial/glacial) has been widely debated for the Neogene; for example, Schrag et al. [1995] showed that equatorial sea surface temperatures (SSTs) were constant through most of the Cenozoic. Others have shown that SST variations between glacial and interglacial states may have been as little as 1 to $2^{\circ} \mathrm{C}$ and were variable between oceans (see, e.g., Sonzogni et al. [1998] for a review). Tropical temperatures may not therefore give an indication of the wider global climate.

[4] To determine whether the predicted stabilization of equatorial temperatures and transition to more modern climate mode during the Mid-Ordovician was a global phenomenon it is also necessary to know the latitudinal temperature gradient and the nature of the deep ocean circulation. Climate models can provide one source of such information. However, few climate models have been attempted for the Ordovician, largely because of the difficulties in quantifying boundary 


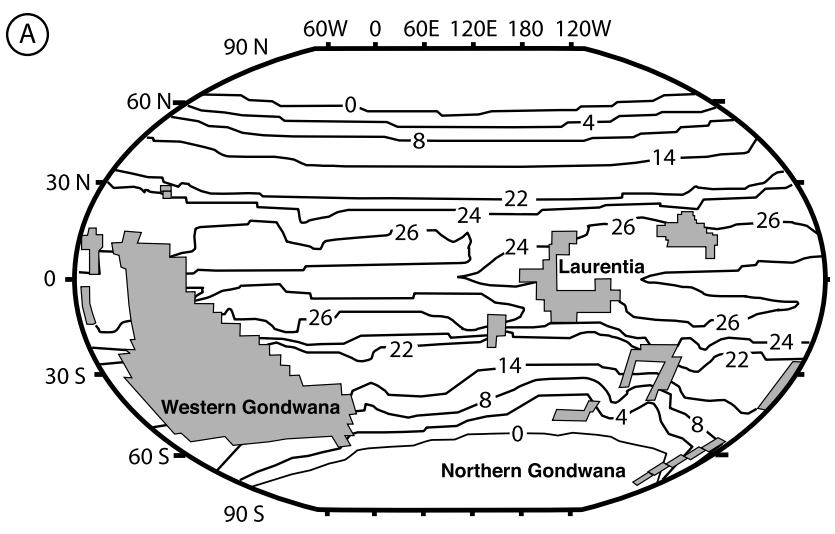

(B)

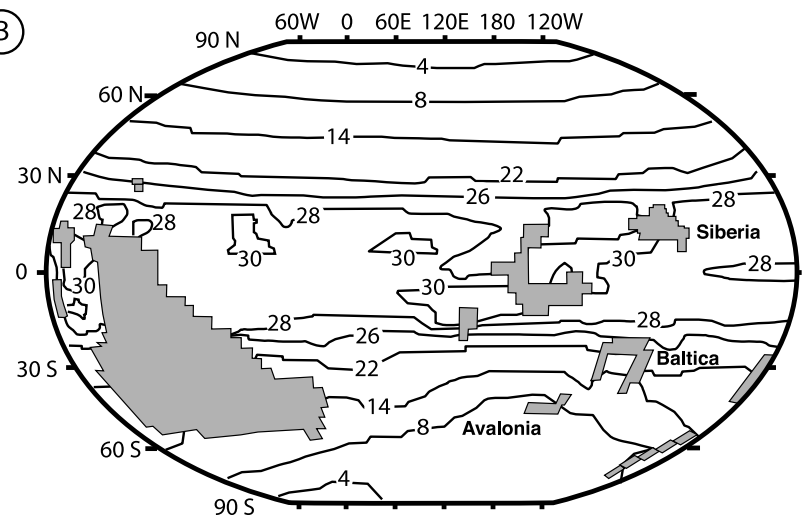

(C)

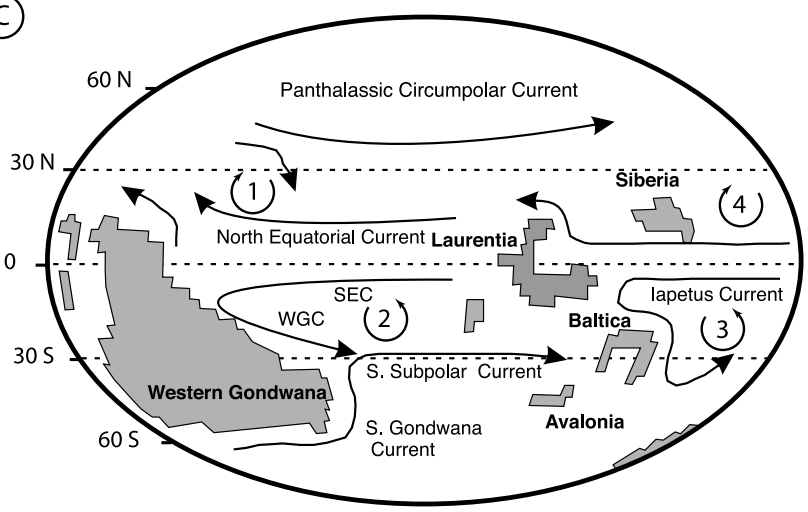

$\bigcup \circlearrowleft$ gyre system

Figure 1. (a, b) SST and (c) sea surface current simulations for the Sandbian-Katian. Models with high relative sea level and with (1) $p \mathrm{CO}_{2}$ at $\mathrm{x} 8 \mathrm{PAL}$ and (2) $p \mathrm{CO}_{2}$ at $\mathrm{x} 15$ PAL [Herrmann et al., 2004]. Figures $1 \mathrm{a}$ and $1 \mathrm{~b}$ are modified from Herrmann et al. [2004], with permission from Elsevier; contours represent mean annual temperatures $\left({ }^{\circ} \mathrm{C}\right)$. Figure 1c is reproduced from Armstrong [2007] which is in turn based on Herrmann et al. [2004]. The numbers represent oceanic gyres [Herrmann et al., 2004]: 1, North Panthalassic Convergence; 2, South Panthalassic Convergence; 3, South Paleo-Tethys Convergence; 4, North PaleoTethys Convergence; SEC, South Equatorial current; WGC, Western Gondwana current. conditions, particularly the $p \mathrm{CO}_{2}$, water vapor content of atmosphere and ocean bathymetry.

[5] Notwithstanding these difficulties, several attempts have been made to model Ordovician climate [Poussart et al., 1999; Herrmann et al., 2004]. Herrmann et al. [2004] (Figure 1) produced SST and surface current simulations, for various sea level and $p \mathrm{CO}_{2}$ scenarios, for the Late Ordovician (Sandbian and lower Katian versus upper Katian to Hirnantian (Figure 2)), from OGCM models. Figure 1 shows their simulations at $\mathrm{x} 8$ Present Atmospheric Level (PAL) and $\mathrm{x} 15$ PAL $p \mathrm{CO}_{2}$ for the Sandbian-lower Katian, with high relative sea level (see Tobin and Bergström [2002, and references therein] for an overview and justification of these elevated levels of atmospheric $\mathrm{CO}_{2}$ ). This time period has been taken to be representative of the preglacial Ordovician greenhouse climate [e.g., Armstrong, 2007] (Figure 2).

[6] Simulations of Ordovician climate suggest paradoxically, that despite relatively high $p \mathrm{CO}_{2}$ values and high sea levels, tropical temperatures and latitudinal temperature gradients were closer to the present day than to extreme greenhouse conditions, such as the PETM [Zachos et al., 2008, and references therein], giving support to the climate stabilization hypothesis of Trotter et al. [2008]. However, the extent to which these computer simulations and the available $\delta^{18} \mathrm{O}$ data truly represent Ordovician conditions remains contentious. Peak Ordovician greenhouse climatic conditions are hypothesized to have occurred during the Nemagraptus gracilis graptolite biozone, apparently coinciding with some of the highest sea levels in the Paleozoic (see papers by Webby et al. [2004a]), about $460 \mathrm{Myr}$ ago, and cooling toward the Hirnantian glaciation only started during the Katian, at the Gutenberg Positive Carbon Isotope Excursion (GICE [Saltzman and Young, 2005]). But, alternatively, the $N$. gracilis biozone just postdates the stabilization of equatorial temperatures to modern values [Trotter et al., 2008] (Figure 2). In the absence of global, high-fidelity stable isotope data, an alternative method is required to ground truth the Mid-Ordovician climate simulations.

[7] The global distribution and abundance of planktonic organisms (e.g., foraminifera, calcareous nannoplankton) has long been known to be primarily controlled by SST [Kucera, 2007, and references therein]. Consequently, the distribution of planktonic foraminifera, preserved in oceanic sediments, has been widely used for reconstructing Quaternary and Neogene oceanic water masses (e.g., see Dowsett [2007] for an overview). Documenting the spatial distribution of fossil planktonic organisms can provide a proxy method for reconstructing the distribution of the climate belts and SST in deep time and hence for testing climate simulations and elucidating global climate state.

[8] Graptolites are known to have been part of the Ordovician zooplankton and species distribution and specimen abundances have been used to develop paleoecological models for graptolites [Cooper et al., 1991; Finney et al., 2007]. These models show both depth, latitude and water mass-specific controls. Cooper et al. [1991] (also see Cooper [1998]), defined a low-latitude Pacific and a high-latitude Atlantic province [see also Skevington, 1974] 


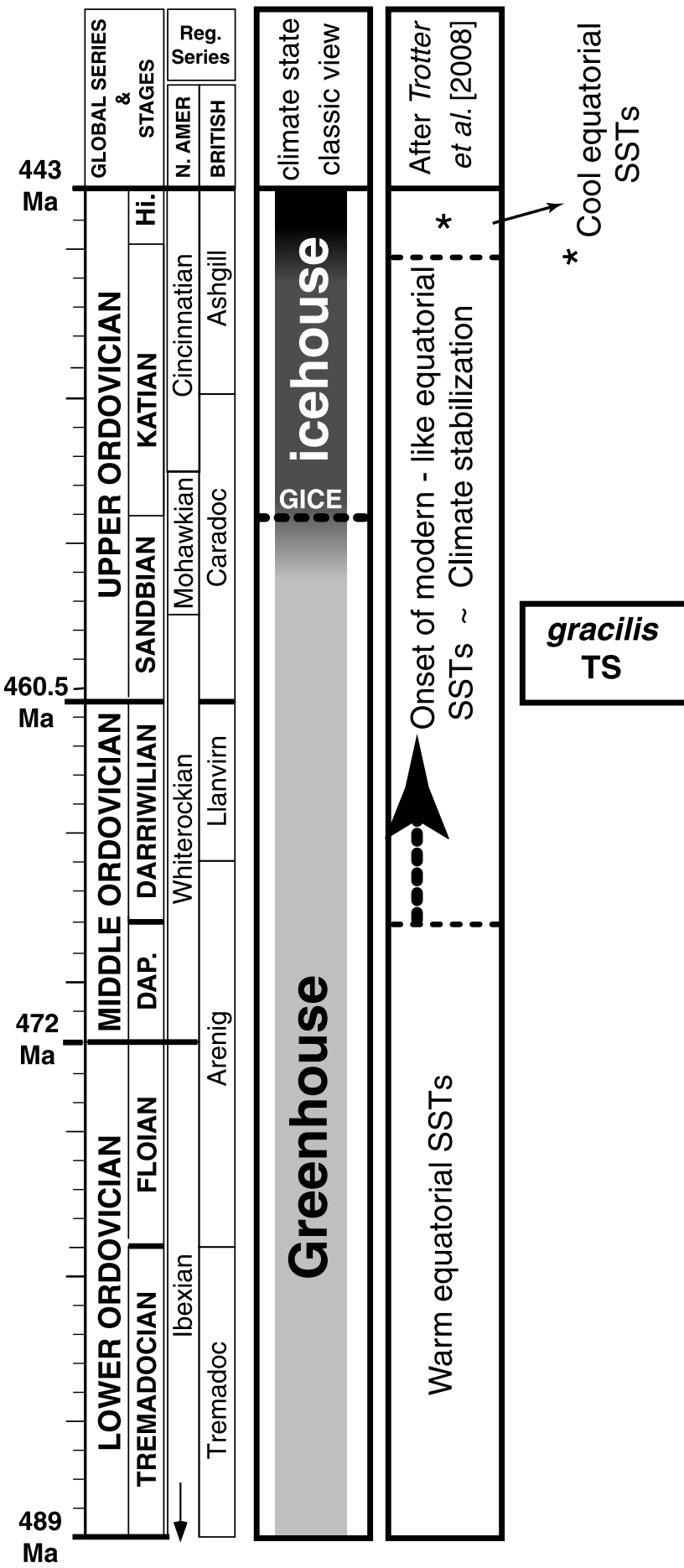

Figure 2. Ordovician chronostratigraphy showing the new international subdivisions and the local British and North American regional series. Compiled after Webby et al. [2004b] and Gradstein et al. [2004]. For references on the "classic view" climate interpretation, with onset of cooling from the GICE onward, see Armstrong [2007] and Page et al. [2007]. The alternative interpretation, with climate stabilization around modern-day values during the Mid-Ordovician is detailed in the text [Trotter et al., 2008]. Our gracilis time slice lies within the interval of maximum discrepancy between both climate interpretations. Hi. is Hirnantian; Dap. is Dapingian. for the Early to Middle Ordovician (prior to our time slice), but considered the majority of graptolites were pandemic at this time. From an ecological point of view, they defined three depth assemblages: an epipelagic biotope, a deep water biotope and an inshore biotope, defining a didymograptid biofacies (a shallow water taphocoenosis) and an isograptid biofacies (a deep water taphocoenosis). Most of the species found in the epipelagic biotope were considered to be eurythermic [Cooper et al., 1991]. In contrast, Finney [1984, 1986] and Finney and Berry [1997] emphasized lateral differentiation as the primary ecological control on graptolite distribution [also see Williams et al., 2003], and used increased graptolite abundance to suggest the location of coastal upwelling systems along the Laurentian margin during the Middle/Late Ordovician. Building on this, Finney and Berry [1997] and Finney et al. [2007, and references therein] also superimposed a depth control on graptolite assemblages, suggesting the majority of graptolites thrived in the oxygen minimum zone (OMZ), below a restricted group of normalograptids indicative of the photic zone.

[9] In this paper we provide the first integrated reconstruction of Ordovician marine biotopes for the Nemagraptus gracilis time slice (see below for definition) on the basis of the paleobiogeographical distribution of graptolite species. We will show that these biotopes have features in common with the distribution of modern planktonic foraminiferal provinces. Thus we are able to map climate belt distribution and test OGCM simulations of SST and infer global climate state.

\section{Methodology}

[10] Our primary research method is based on the compilation of species presence/absence data from sections of known paleogeography within a well-constrained time slice, followed by the elucidation of community structure within these data. This methodology has most recently been applied for climate reconstructions in the Pliocene (Pliocene Research, Interpretation and Synoptic Mapping, PRISM; see Dowsett [2007] for an overview and further references).

\subsection{Time Slice Definition}

[11] The gracilis graptolite biozone is defined by the first appearance of the eponymous species Nemagraptus gracilis, a widely recognized biostratigraphical marker for the base of the Upper Ordovician [Bergström et al., 2000] (Figure 2). The time slice we are introducing here is defined by the total range of this species and is largely coincident with, but not identical to, the eponymous biozone. We adopt this definition for three reasons: (1) the definition of the gracilis biozone is different on several paleocontinents (e.g., $N$. gracilis ranges into the $C$. bicornis biozone in N. America), (2) the biozonal concept has changed through time (for an overview, see Williams et al. [2004]) and, (3) graptolite faunas from the southerly high latitudes of Gondwana do not contain $N$. gracilis, but the contemporaneous Oepikograptus bekkeri [GutiérrezMarco et al., 1995]. Figure 3 shows how our gracilis time slice is defined; taking this approach, it probably represents 

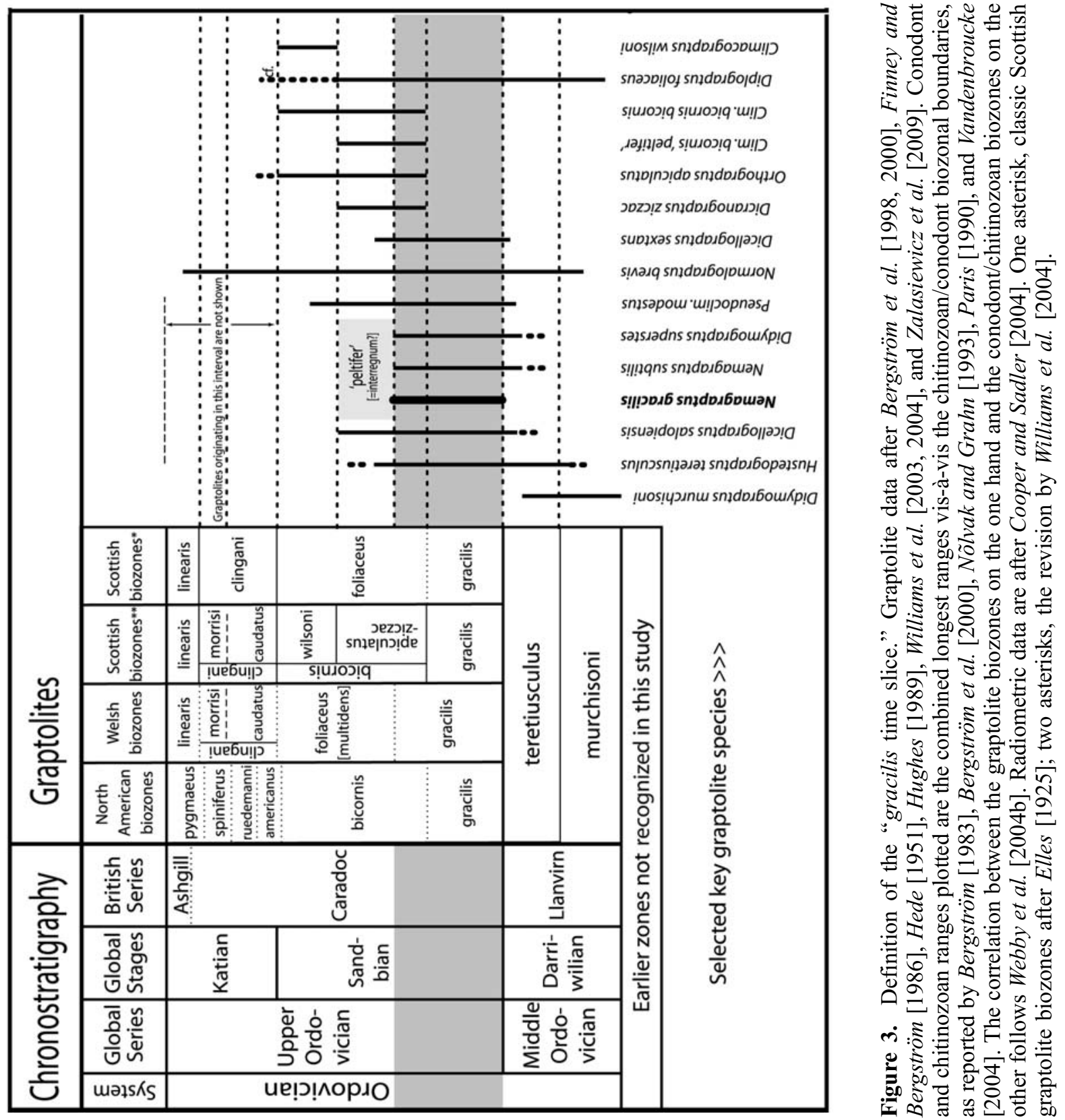


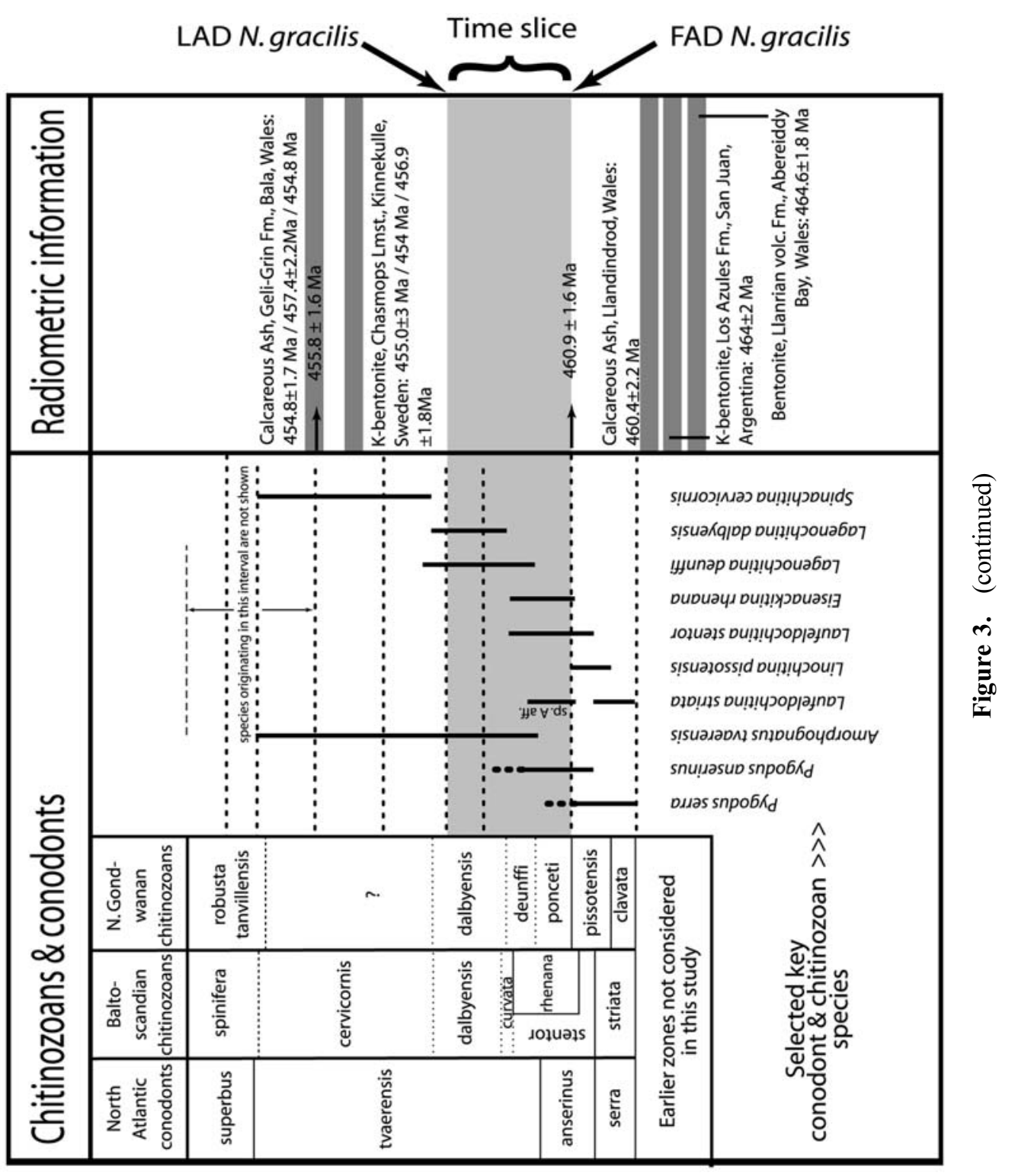


(A)

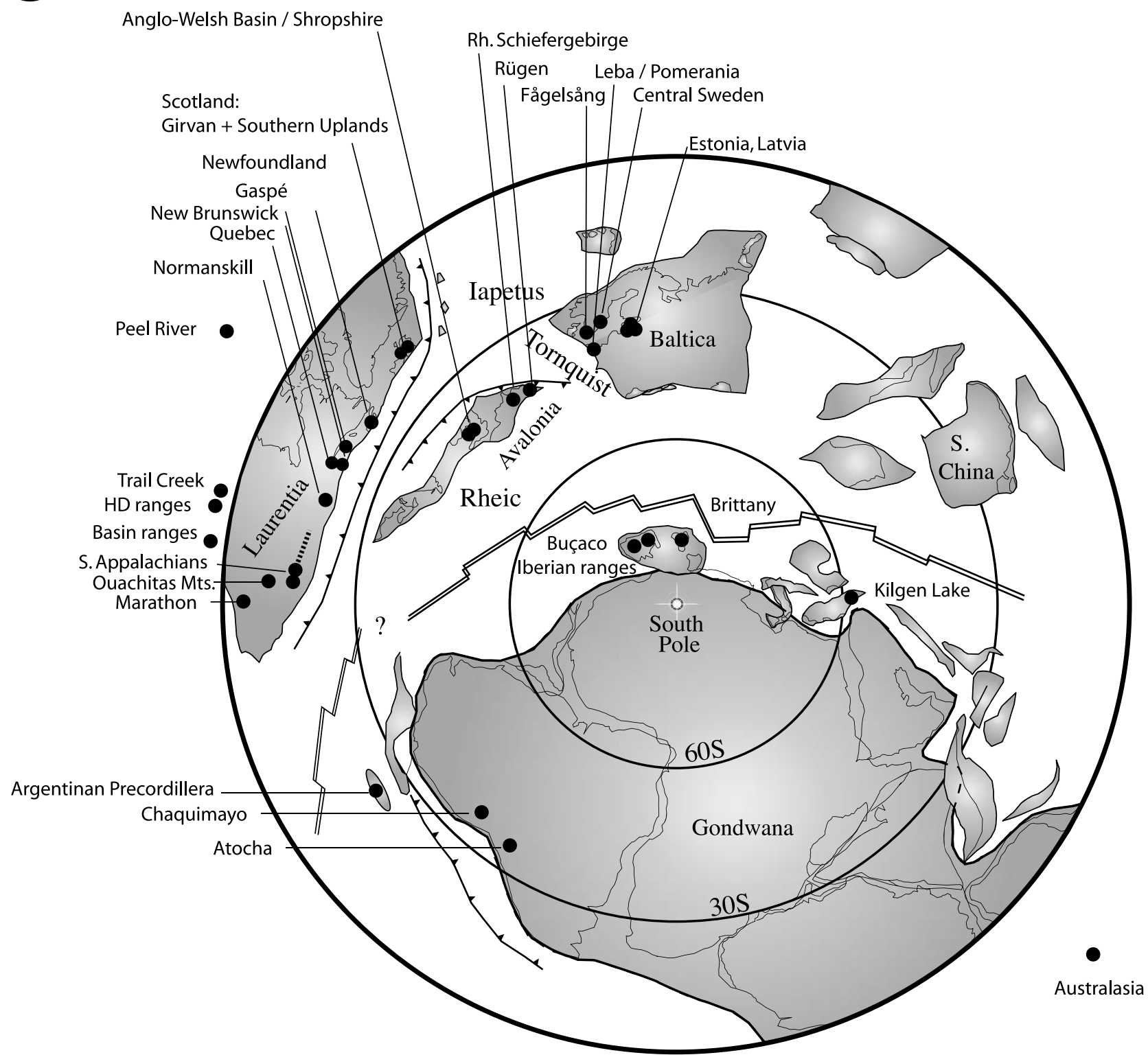

Figure 4. Late Ordovician paleogeographical reconstructions showing the distributions of the sections in this study: (a) paleogeographic terrane map of Cocks and Torsvik [2004] and (b) paleogeographic map after C. R. Scotese (2002, http://www.scotese.com (PALEOMAP Web site)). The gray areas are landmasses (but note that this is not the case in Figure 4a). The actual "point tracker" coordinates of the sections, as used in the analyses, can be found in Table S1.

about 3 to 4 million years (on the basis of the timescale proposed by Webby et al. [2004b]).

\subsection{Database Construction}

[12] In constructing the database we have interrogated all of the major literature sources, and have tried to include data from all the key sections (Table S1). ${ }^{1}$ Because of the history

\footnotetext{
${ }^{1}$ Auxiliary materials are available in the HTML. doi:10.1029/ 2008PA001720.
}

of collecting and study, the majority of these sections lie on the paleocontinents that surrounded the Iapetus Ocean. The historical nature of the published literature and recent taxonomic revisions of Ordovician graptolite species has necessitated minor taxonomic filtering of the taxa included in the database. In this we have taken a pragmatic approach and limited our revisions largely to generic reassignments, with a few exceptions (see Table S2). The data matrix (auxiliary material) also includes some entries of species in open nomenclature ("?" and "cf.," but never "aff." 


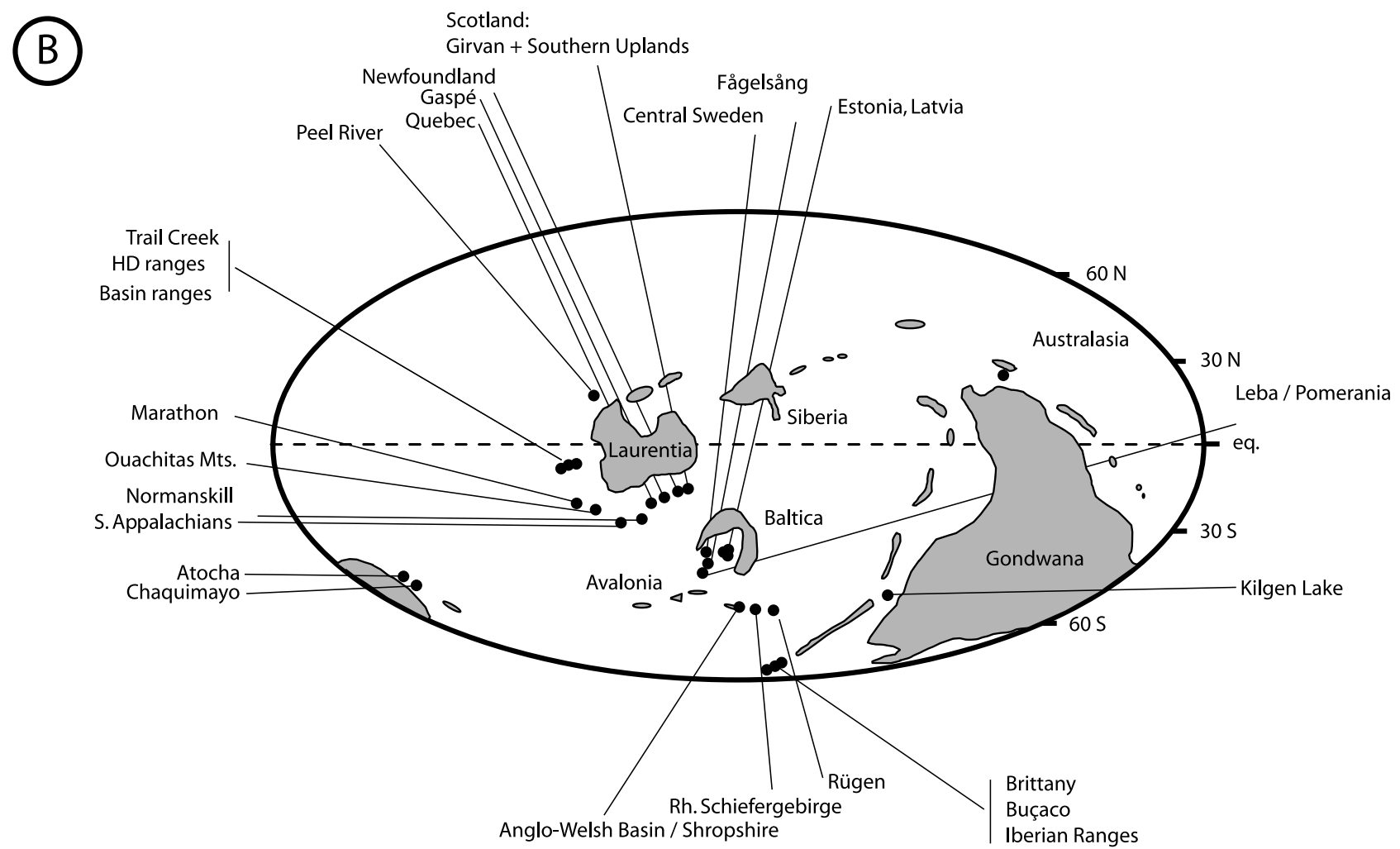

Figure 4. (continued)

following the conventions of Bengtson [1988]). Compilations that provide illustrative (thumbnail) sketches of the key taxa used in this study include Vandenberg and Cooper [1992] and Zalasiewicz et al. [2009].

[13] The paleolatitude of the sections included (Table S1 and Figure 4) has been derived from two widely accepted paleogeographical reconstructions, from Scotese (and calculated using Point Tracker software (www.scotese.com)) and that of Cocks and Torsvik [2004]. The position of a single location can vary by up to $5^{\circ}$ of latitude when plotted on these two reconstructions, and this defines our maximum paleogeographical error and the minimum "bin size" used for compiling the simplified presence/absence matrix (see below). More pronounced differences in the paleolatitudes of some sections (up to $15^{\circ}$ ) are due to the varying position of Avalonia, $\sim 35^{\circ} \mathrm{S}$ or $\sim 55^{\circ} \mathrm{S}$, and slight differences in the position of Laurentia (straddling the equator or mainly south of it). In such cases we have defaulted to the paleogeographical reconstructions proposed by Scotese and McKerrow [1990] (using point tracker, see above) and used in the Herrmann et al. [2004] climate simulations

[14] The paleogeographical reconstructions are based on a wide range of geological data including fossil distributions. Continental margins have been constrained using shallow marine invertebrate species and though the Cocks and Torsvik [2004] reconstructions include some graptolite distribution data, none are from the gracilis time slice (L. R. M. Cocks, personal communication, 2008). In our location maps we have included paleocontinental positions for Baltica,
Gondwana, Laurentia and Avalonia as these provide a reference frame that marks the boundaries of the Iapetus Ocean and its subbasins. All sections are representative of marine environments and locality maps and the stratigraphy of the sections are shown in Figures 4 and 5, respectively. Where possible each section has been attributed to a position on a shelf-to-basin transect, on the basis of descriptions from the literature; this then allows us to discriminate shelf (or shelf-going) and nonshelf species, as used to determine the relative depth of graptolite biotopes by Cooper et al. [1991].

\subsection{Data Analysis}

[15] A species presence/absence matrix has been compiled from the database (auxiliary material) for the gracilis time slice. To elucidate any ecological structure within this matrix we have applied two quantitative analyses (Figure 6). First, TWINSPAN, "two way indicator species analysis," was used to elucidate the higher-level ecological structure in our presence-absence data set. TWINSPAN is a widely used, hierarchical clustering method that creates clusters of species and samples on the basis of the repeated, dichotomous division of an ordination space [Hill, 1979]. Second, we constrained latitude and reordered the presenceabsence data to produce latitudinally constrained subgroups of graptolite taxa, herein considered biotopes (see Hammer and Harper [2006] for detailed methodology). The resultant presence/absence matrix has then been simplified by the grouping of localities into bins of $5^{\circ}$ paleolatitude, to encompass the paleogeographical error (Figure 7). 


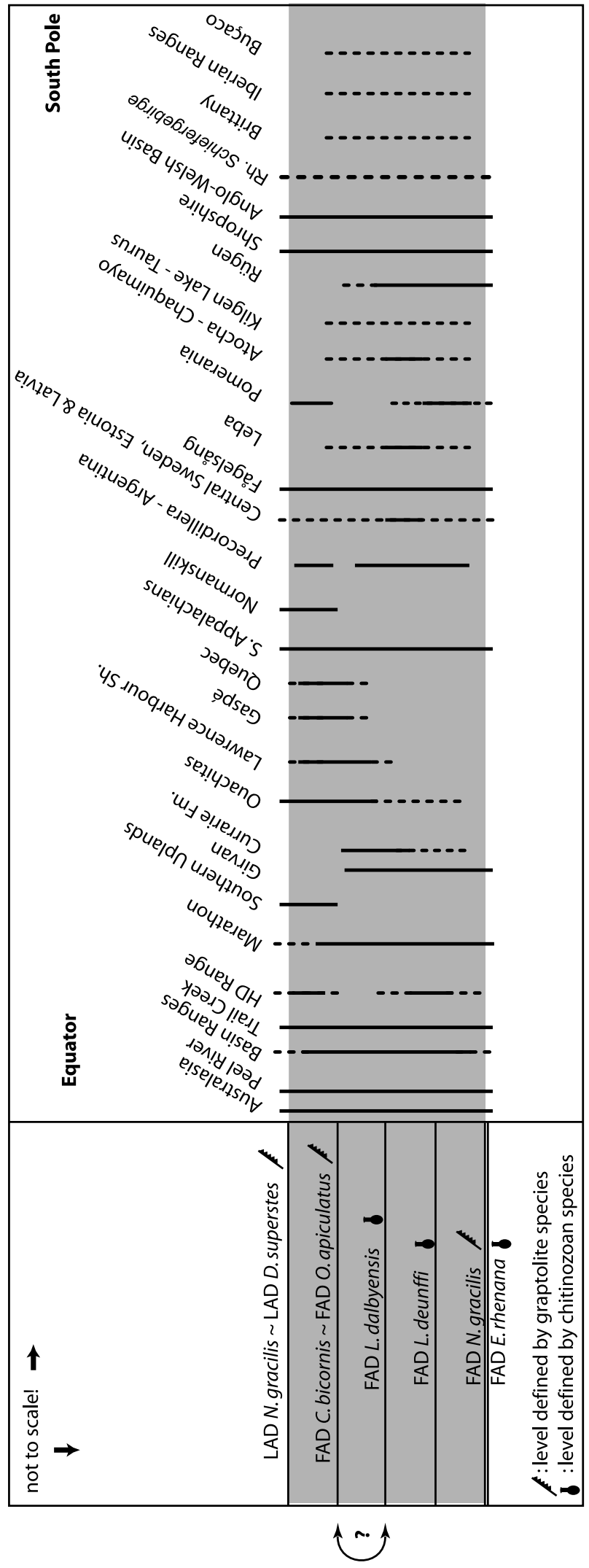

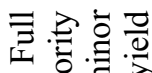

的寻芯

荡焉

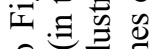

을.引

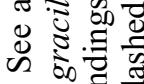

$\dot{\vec{c}} \dot{\mathrm{o}}$

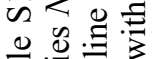

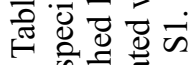

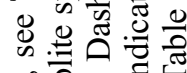

के

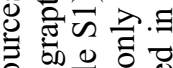

o

임

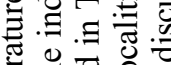

헝 용.

比氞。

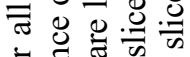

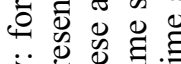

艺芑导寻

总

๖ ธี

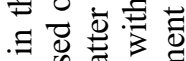

규

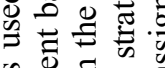

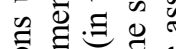

.

क छ 0 .

\& $0_{0}$ की.

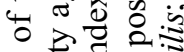

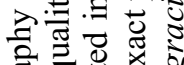

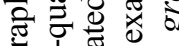

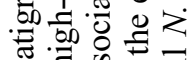

ज्ञ

䒕

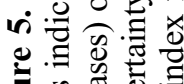

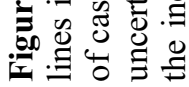


Definition of the Biotopes

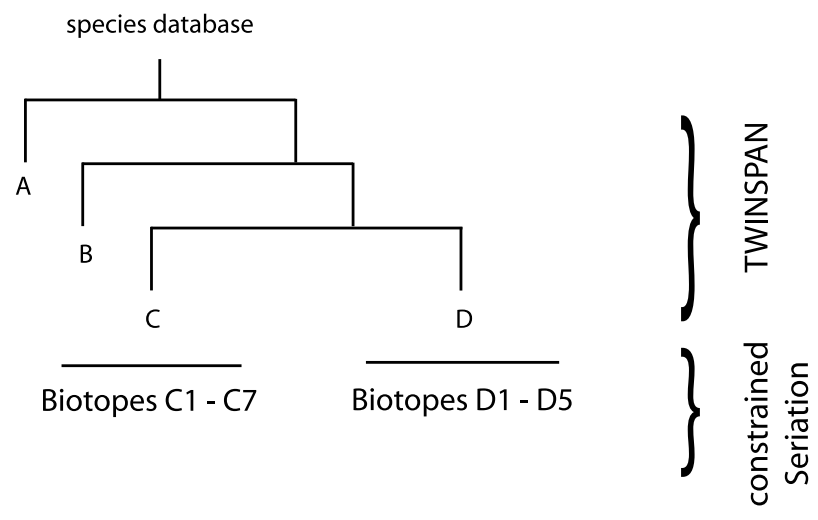

Figure 6. TWINSPAN tree, showing TWINSPAN groups $\mathrm{A}-\mathrm{D}$ and graptolite biotopes $\mathrm{C} 1-\mathrm{C} 7 / \mathrm{D} 1-\mathrm{D} 5$. For more information, see text.

\subsection{Hypothetical Zooplankton Model}

[16] At the global scale five planktonic foraminiferal "provinces" are recognized: Tropical, Subtropical, Temperate (or Transitional), Subpolar and Polar and specific composition is generally the same for corresponding provinces in adjacent hemispheres [Kucera, 2007]. These provinces strongly correlate with modern climate zones. The temperature and latitudinal positions of these provinces are listed in Figure 8a. We have used the present-day SST for the province boundaries and the Herrmann et al. [2004] models (Figure 8b), to infer the latitudinal ranges of these provinces in the Ordovician (Figure 9). The hypothetical zooplankton models provide us with an indication of how the positions of the climate zones would vary under different levels of atmospheric $p \mathrm{CO}_{2}$ and provide a test of whether the graptolite biotopes are comparable to planktonic foraminiferal provinces at the present day, i.e., whether they reflect the climate zones.

\section{Results}

[17] TWINSPAN analysis divides the graptolite data into four high-level groups (A to D (see Figure 6)). These groups are considered equivalent to high-level ecological groupings (e.g., provinces, "major subdivisions of the biosphere," according to Lincoln et al. [1998]). Further subdivisions of the TWINSPAN groups by constrained seriation results in a number of subgroups herein called biotopes ("the smallest geographical unit of the biosphere or of a habitat that can be delimited by convenient boundaries and is characterized by its biota" as defined by Lincoln et al. [1998, p. 42]).

[18] TWINSPAN group A comprises Climacograptus brevis mutabilis, Orthograptus uplandicus and Oepikograptus bekkeri. O. bekkeri is its most characteristic faunal element and has been recovered from shelfal sections in the middle to high southerly paleolatitudes $\left(35^{\circ} \mathrm{S}\right.$ to $75^{\circ} \mathrm{S}$ (Figures 7 and 9)). It is the only graptolite species reported from northern Gondwana in this time slice and its biotope is the only one to contain a species that ranges south of $55^{\circ} \mathrm{S}$. TWINSPAN group A contains too few taxa and samples to allow for further subdivision using constrained seriation; therefore, TWINSPAN group A also represents biotope A.

[19] TWINSPAN group B consists of Dicellograptus divaricatus salopiensis and Diplograptus molestus only. Both are present in sample "Central Sweden," which also comprises species typical of TWINSPAN group A. However, they also occur in samples typical of TWINSPAN groups C and D (e.g., Welsh Basin, Australia, etc.). As a result, the TWINSPAN analysis assigned them to a separate TWINSPAN group (B), which has little geographical relevance and will therefore not be considered further in our geographical analysis.

[20] TWINSPAN groups $\mathrm{C}$ and $\mathrm{D}$ have similar paleogeographical distributions from $15^{\circ} \mathrm{N}$ to $55^{\circ} \mathrm{S}$ (Figures 7 and 9) and are the most taxonomically diverse of all the TWINSPAN groups. Constrained seriation defines biotopes $\mathrm{C} 1$ to $\mathrm{C} 7$ and D1 to D4 (Figures 7 and 9). Full species lists for each biotope are presented in Appendix A. For each biotope, the spatial distribution patterns of the species included are detailed below and illustrated in Figure 9. Typically, each biotope contains species with narrow latitudinal ranges and species with wide paleogeographical ranges that spread from low to high latitudes. The latitudinal ranges of the narrowly restricted species within each biotope define restricted zones as detailed below from $\mathrm{N}$ to $\mathrm{S}$.

[21] Biotope C1 (25 species) has the most wide-ranging species, from $10^{\circ} \mathrm{N}$ southward, and includes Nemagraptus gracilis gracilis and Climacograptus bicornis bicornis. Biotope C2 (11 species) has, among others, the latitudinally restricted species Orthograptus amplexicaulis and Dicranograptus ziczac that appear at $5^{\circ} \mathrm{S}$, next to wider ranging species such as Hustedograptus teretiusculus. The latitudinally restricted species of Biotope C3 (22 species) appear at $20^{\circ} \mathrm{S}$, and include Thamnograptus scoticus next to widespread species such as Dicranograptus brevicaulis and Diplograptus foliaceus. The most restricted species of biotope C4's (4 species), Corynoides curtus pristinus, appears at $25^{\circ} \mathrm{S}$. Biotope $\mathrm{C} 5$ (6 species) has the latitudinally restricted species Dicranograptus kirki and Dicranograptus spiniferus that appear at $35^{\circ} \mathrm{S}$. Biotopes C6 (12 species, including Dicellograptus pumilus and Glossograptus scanicus) and C7 (4 species, including Climacograptus sheldoni and Didymograptus euodus) are restricted to $\sim 40^{\circ} \mathrm{S}$ and $\sim 55^{\circ} \mathrm{S}$, respectively.

[22] Biotopes D1 to D5 contain species with a similar, if not identical, distribution pattern to those in the $\mathrm{C}$ biotopes.

Figure 7. Simplified presence-absence matrix based on TWINSPAN and constrained seriation analysis. Sections have been amalgamated into $5^{\circ}$ latitude "bins" for pattern recognition and reproduction purposes. For a full-scale, unamalgamated version of the presence-absence matrix, see auxiliary material. (C. R. Scotese, 2002, http://www.scotese.com (PALEOMAP Web site.)) 
Simplified graptolite matrix using Paleolatitudes created by Point tracker (ScotesePALEOMAP). Twinspan groups A-D have been subjected to constrained seriation to observe their internal patterns and to produce biotopes A, C1-7 and D1-5.

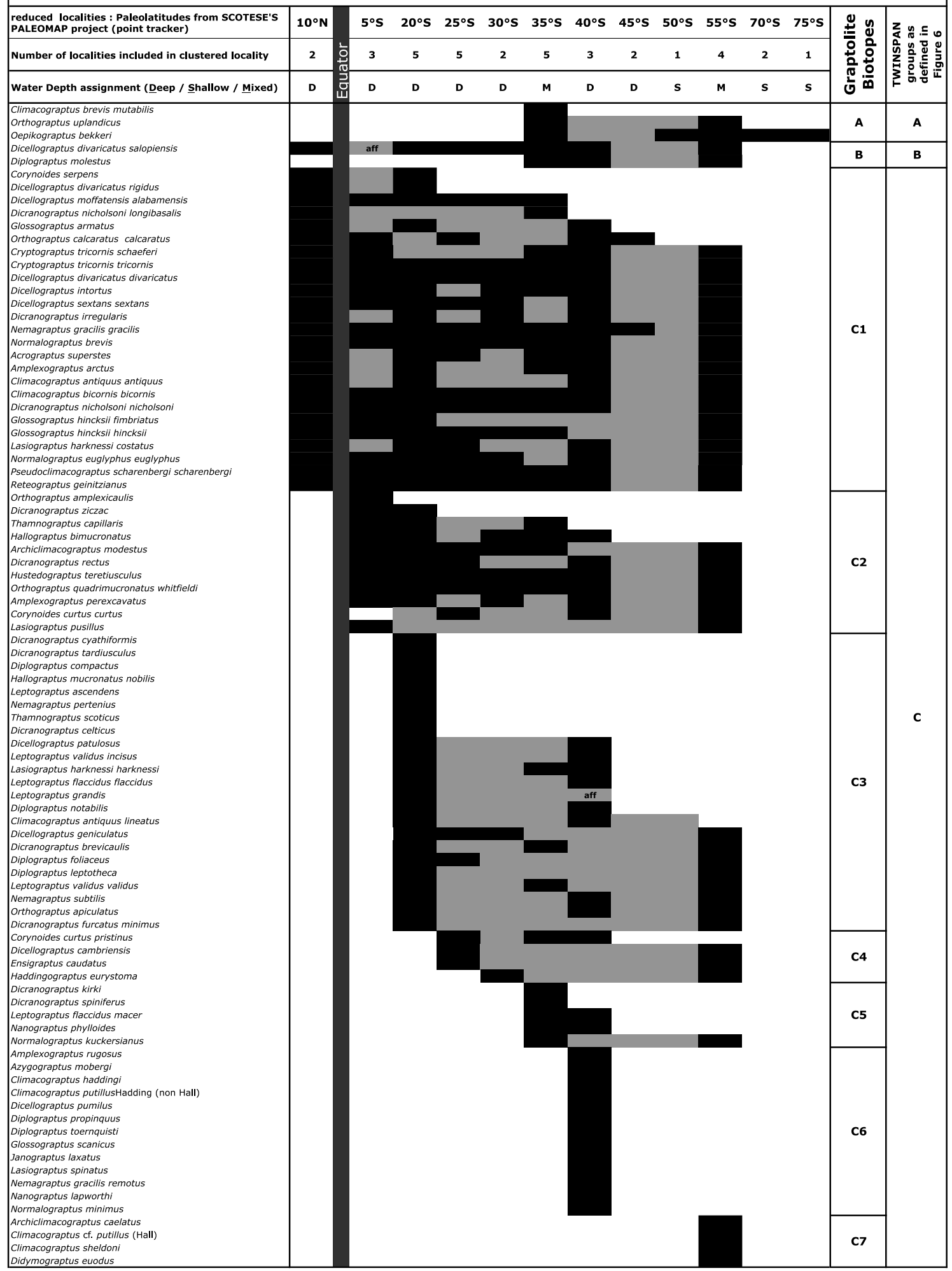

Didymograptus euodus 


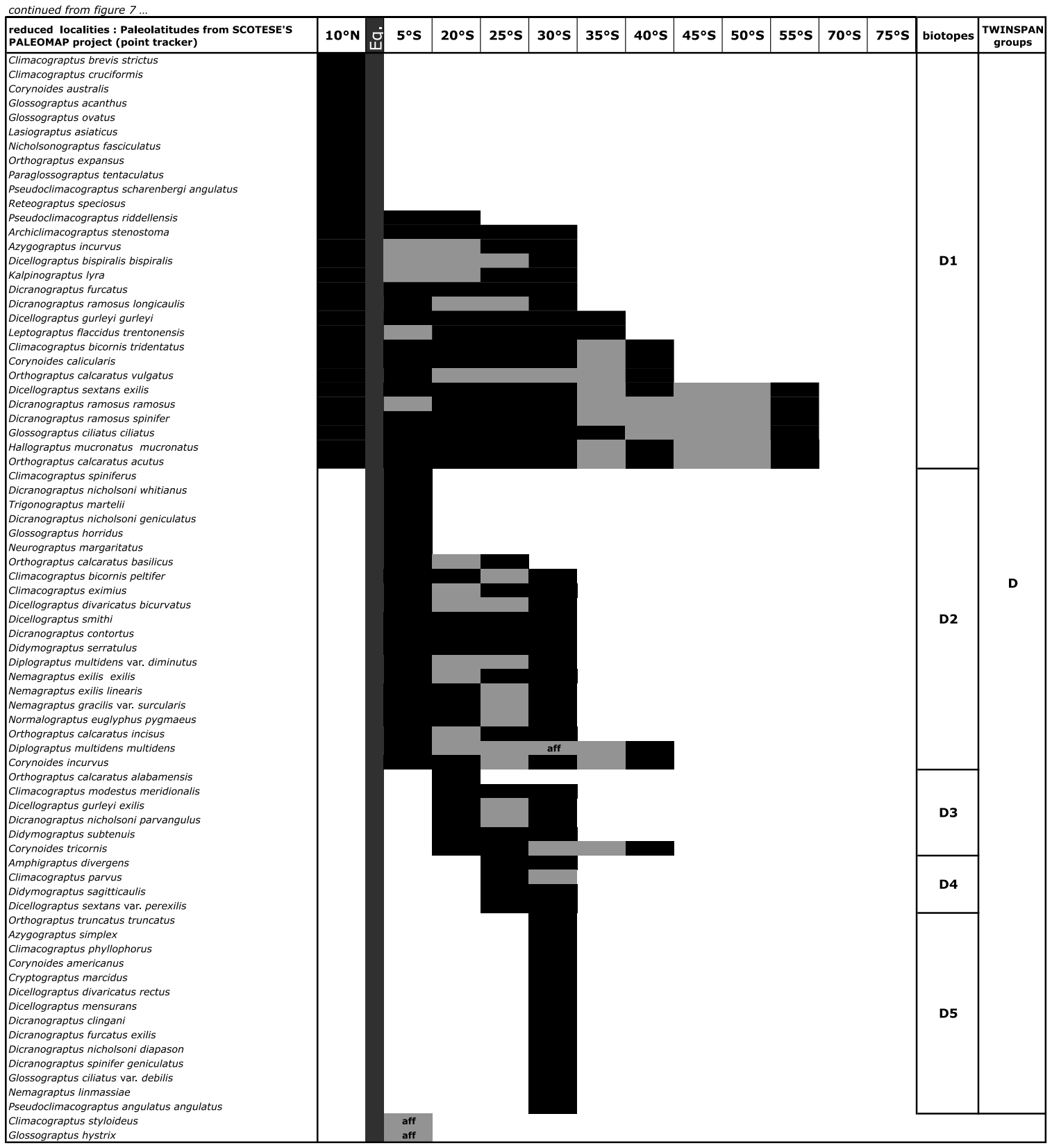

Figure 7. (continued)

Again, the narrow-ranging species within each D biotope define biotope boundaries that are coincident with those of Biotopes C1 to 4. Biotope D1 (29 species) has, among others, the latitudinally restricted species Climacograptus cruciformis and Nicholsonograptus fasciculatus from $10^{\circ} \mathrm{N}$ southward, next to wider-ranging species such as Climacograptus bicornis tridentatus and Corynoides calicularis. Biotope D2 (21 species) has latitudinally restricted species such as Climacograptus spiniferus that appear at $5^{\circ} \mathrm{S}$, next to wider ranging species such as Climacograptus bicornis peltifer. The most restricted species of biotope D3 (6 species), Orthograptus calcaratus alabamensis, appears at $20^{\circ} \mathrm{S}$, and this biotope's wider-ranging species include Cory- noides tricornis. The four species of biotope D4 include Climacograptus parvus and Didymograptus sagitticaulis. Biotope D5 (14 species, including Orthograptus truncatus truncatus and Pseudoclimacograptus angulatus angulatus) is restricted to $\sim 30^{\circ} \mathrm{S}$.

\section{Interpretation}

\subsection{Implications for Graptolite Ecology Models}

[23] Figure 10 is a plot of section locations on a continental shelf-to-basin transect. Species characteristic of TWINSPAN Group A are restricted to high-latitude platform-shelf settings. Species that characterize TWINSPAN Group $\mathrm{C}$ range across the shelf-to-basin transect in middle 


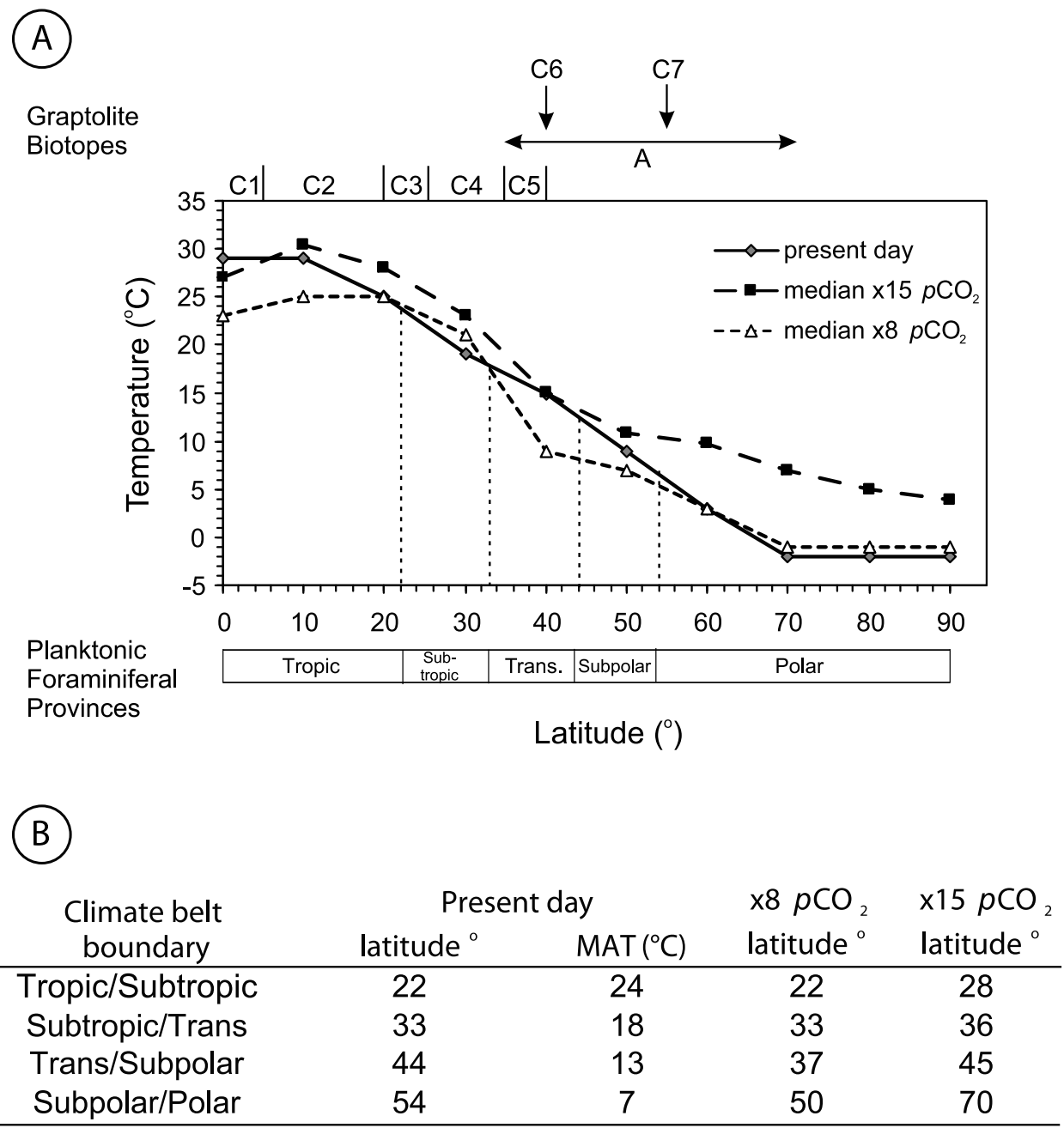

Figure 8. (a) Latitudinal temperature profiles from the Herrmann et al. [2004] models ( $\mathrm{x} 8$ and $\mathrm{x} 15 \mathrm{PAL}$ $p \mathrm{CO}_{2}$ ) and the present day (taken from www.noaa.gov; also see Locarnini et al. [2006], central Pacific Ocean). This plot also shows the distribution of modern planktonic foraminiferal provinces and Ordovician graptolite biotopes with latitude. (b) The boundaries of modern-day planktonic foraminifera provinces expressed in terms of SST (taken from Kucera [2007]) and the latitudinal position of this temperature boundary as read from Figure 8a for the present day (taken from www.noaa.gov; see above). These boundaries are reexpressed for the Sandbian on the basis of SST simulations of Herrmann et al. [2004] at $\mathrm{x} 8$ and $\mathrm{x} 15$ PAL $p \mathrm{CO}_{2}$ from Figure 8a and allow an estimate of the appropriate position of these provinces/climate belts during different Ordovician $p \mathrm{CO}_{2}$ scenarios. For example, the tropical/subtropical province boundary $\left(24^{\circ} \mathrm{C}\right.$ [Kucera, 2007]) lies at $22^{\circ} \mathrm{S}$ at the present day, lies at $28^{\circ} \mathrm{S}$ during the Sandbian with $x 15$ PAL $p \mathrm{CO}_{2}$, and lies at $22^{\circ} \mathrm{S}$ during the Sandbian with $\mathrm{x} 8 \mathrm{PAL} p \mathrm{CO}_{2}$. The two Ordovician sets of latitudes provide the hypothetical boundaries for Sandbian zooplankton distribution as shown in Figure 9. MAT, mean annual temperature.

to low latitudes. Species that characterize TWINSPAN Group D are restricted to sections in an outer shelf to basin/slope setting and do not occur on the shelves. In order for species within TWINSPAN Group $\mathrm{C}$ to have ranged across shelf into basinal settings they must have been epipelagic and occupied the upper part of the water column. Species within TWINSPAN Group D invariantly are non-shelf going; this can be explained by one of the following hypotheses.
[24] 1. The non-shelf going species were deeper water, perhaps mesopelagic or bathypelagic. This is the depth stratification model of Cooper et al. [1991, Figure 4A, p. 207], and according to their definitions, species of TWINSPAN group D (equivalent to Cooper et al.'s deep water "biotope") were living below the epipelagic species of TWINSPAN group C (equivalent to Cooper et al.'s epipelagic biotope (Figure 11a)).

[25] 2. Species within TWINSPAN Group D lived at the same general depth as epipelagic species of TWINSPAN 


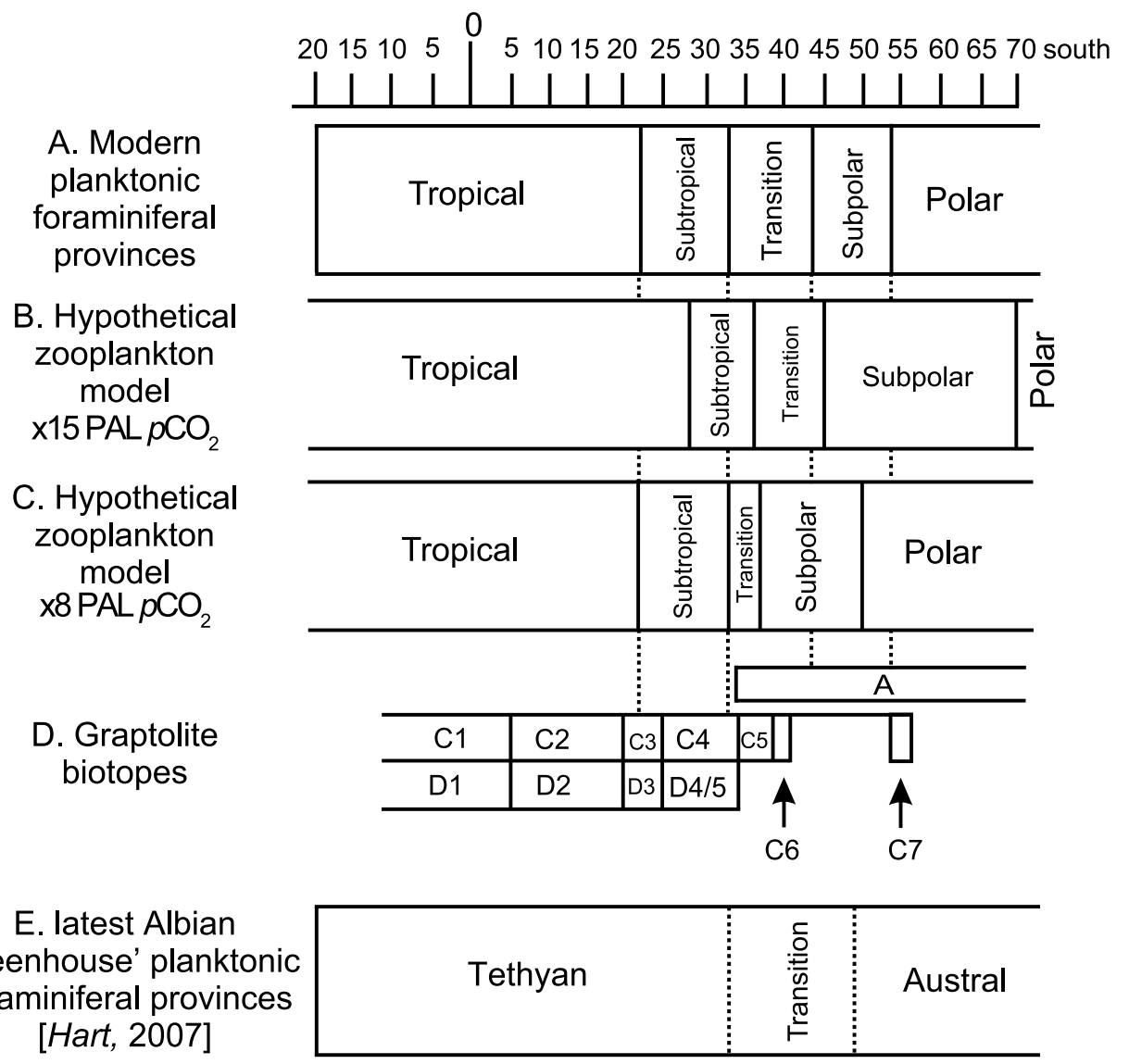

Figure 9. (a) Modern-day planktonic foraminifera provinces with boundaries defined as explained in Figure 8. (b and c) Hypothetical zooplankton models for Ordovician climate simulations at x8 and x15 $p \mathrm{CO}_{2}$ with boundaries defined as explained in Figure 8. These show how the climate zones could change with different levels of $p \mathrm{CO}_{2}$. (d) The graptolite biotope distributions from Figure 7. (e) Late Albian planktonic foraminifer provinces from Hart [2007].

group $\mathrm{C}$, but were confined to the open oceanic part of the epipelagic zone (Figure 11b), much in the same way that certain present-day zooplankton do not cross the shelf break [Raymont, 1983]. This is based on Cooper et al.'s [1991, Figure 4B, p. 207] alternative for their depth stratification model, and close to the ecological models of Finney [1984, 1986].

[26] 3. The non-shelf going species of TWINSPAN Group D were restricted to shelf margin waters, indicative of upwelling zones (as suggested by, e.g., Finney and Berry [1997]) (Figure 11c).

[27] 4. These were shelf-going species that are not recognized as such because of the absence of graptolite-bearing, shelfal sections at the paleolatitudes occupied by these species (Figure 11d).

[28] We are now able to critically evaluate the depth stratification model where C lives above D [Cooper et $a l ., 1991]$. As indicated in the results section, TWINSPAN groups $\mathrm{C}$ and $\mathrm{D}$ have highly similar biotope structures (compare the distribution patterns of $\mathrm{C} 1$ to $\mathrm{C} 7$ with those of D1 to D5) and boundaries coincide between biotope $\mathrm{C} 1$ to $C 7$ and D1 to D5, respectively (Figures 7 and 9). This indicates a common ecological control on spatial distri- bution of the latitudinally restricted graptolites within these biotopes. Below, in section 4.2, we argue that the primary control on the distribution of biotopes $\mathrm{C} 1$ to $\mathrm{C} 7$ is temperature. If the species of TWINSPAN group D truly represent deep water species, living below the epipelagic taxa of group $\mathrm{C}$, and separated from them by a physical boundary (e.g., the thermocline, pycnocline, OMZ), they could not be controlled by the same ecological agent and the identical distribution patterns between biotope $\mathrm{C} 1$ to C7 and D1 to D5 could not be explained. Taken in toto, we suggest that species of TWINSPAN groups C and D occupied similar water depths. Therefore, we favor models explaining the ecology of graptolites that primarily use lateral differentiation (second and third hypotheses above [cf. Finney and Berry, 1997]) above those that use depth stratification [Cooper et al., 1991].

[29] The second and third hypotheses represent different levels of complexity of the same general concept and hence are less easily weighted against each other. The fact that no new endemic D biotope species (absence of D6, D7) occur south of $35^{\circ} \mathrm{S}$ may be explained by specific (upwelling?) conditions around the Laurentian/Australian margins, that are not present in the deeper water sections we used more to 


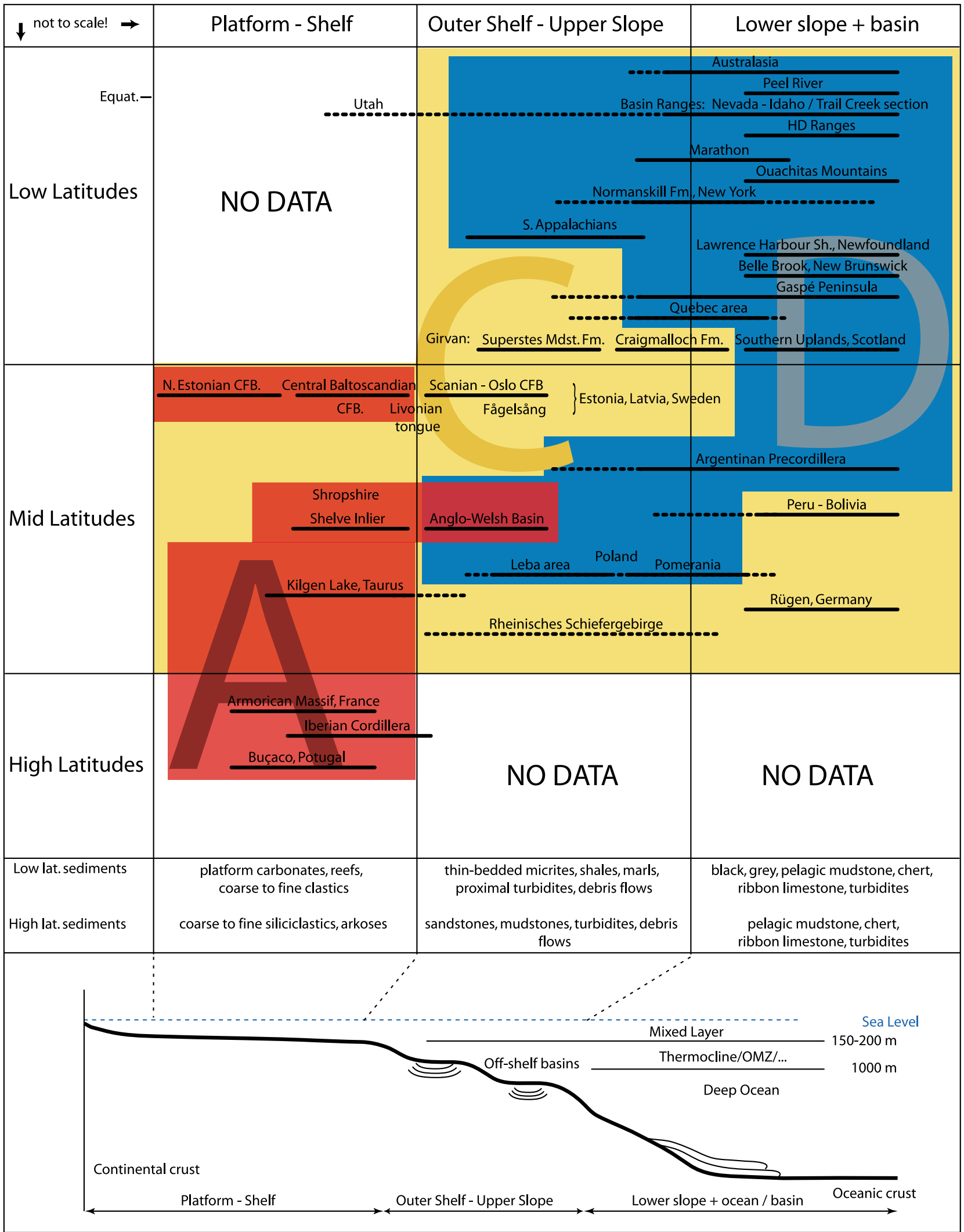

graptolite locality

Figure 10. TWINSPAN groups plotted on a Cooper et al. [1991] type diagram (shelf-to-basin transect versus latitude) that illustrates that TWINSPAN group $\mathrm{C}$ is shelf going and TWINSPAN group D is not. For all literature sources, see Table S1. 


\section{Graptolites that have only been observed in deep water sections $\left(^{*}\right)$ can have one of the following four types of distributions:}
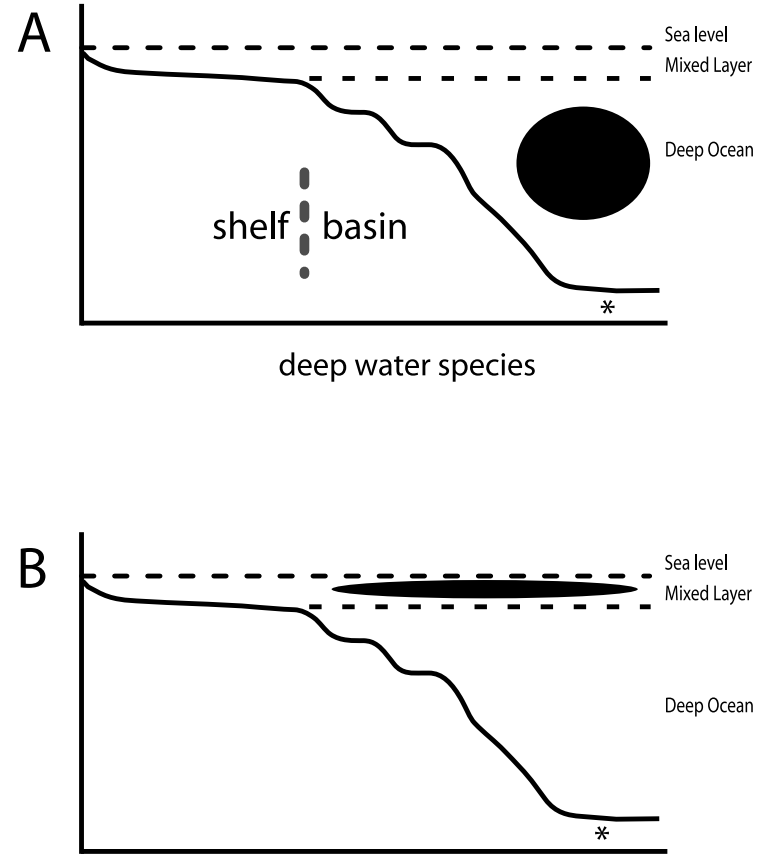

epipelagic, not shelf-going
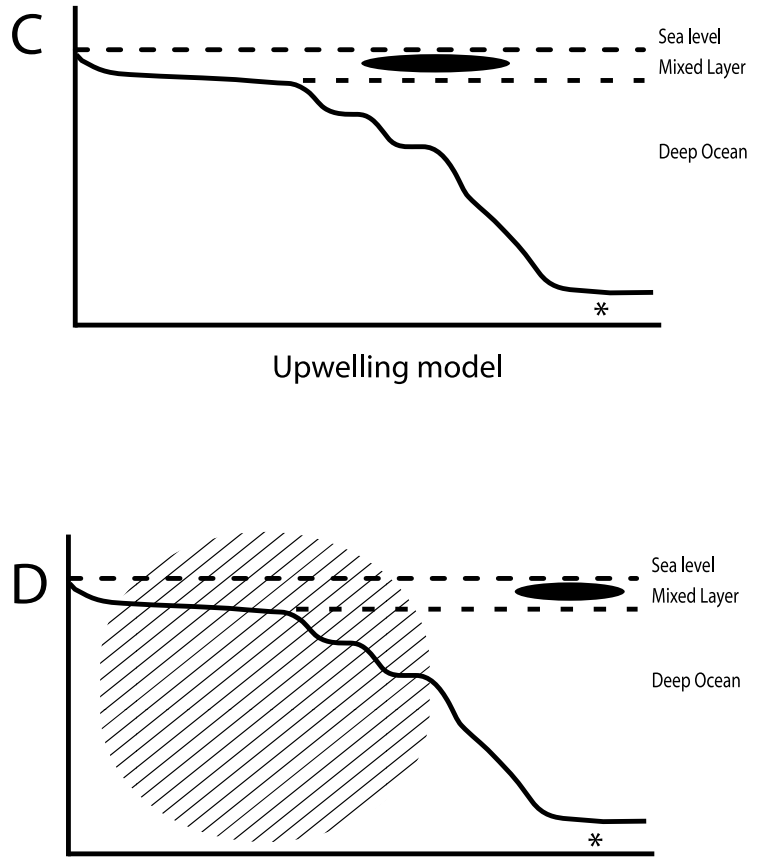

epipelagic, restricted to a paleolatitudinal belt where there are no shelf sections

Figure 11. Species from TWINSPAN group D are only observed from deep water (i.e., nonshelf) sections (asterisks) which can be explained in four discrete ways: (a) these species represent deeper water assemblages, i.e., the deep water biotope of Cooper et al. [1991]; (b) these species are epipelagic but are confined to the open ocean; (c) these species are restricted to shelf margin waters, indicative of upwelling zones [Finney and Berry, 1997]; or (d) these species are shelf-going species that are not recognized as such because of the absence of graptolite-bearing, shelfal sections at the paleolatitudes occupied by these species. On the basis of our analysis, we favor the options in Figures $11 \mathrm{~b}$ and 11c.

the South (e.g., the Welsh Basin sections, and "deeper" parts of the Baltoscandian ramp).

[30] These lateral differentiation models, supported by our data, also explain why the data set is biased toward deeperwater settings (see Figure 10). The fourth hypothesis above (which suggests that shelf-going species could remain undiscovered or were not preserved because of the nature of the deposits) is mentioned for completeness, but the presence of species from deep-water sections at midlatitudes (e.g., the Welsh Basin), where shallow-water sections are present (e.g., Shropshire) weakens this argument. It may still account for some of the species at low latitudes, which makes this a testable hypothesis.

\subsection{Significance and Distribution of Biotopes} A/C1-C7/D1-D5

[31] The distribution of epipelagic species within TWINSPAN Groups C and D should have similar ecological controls to the modern zooplankton. At a global scale, four factors are evident in the distribution of modern zooplankton: (1) zooplankton provinces and water mass distributions can be correlated, but vast areas of "mixed faunas" result at the margins of the oceanic gyres [Cifelli and Stern Benier, 1976; Kucera, 2007], (2) planktonic species are markedly stratified with depth and seafloor samples are composites of the entire water column (see Armstrong and Brasier [2005] for a review), (3) some species are eurythermal and therefore have broad latitudinal ranges and, (4) species can survive under a wide range of SSTs, while their optimum ranges are narrow [Kucera, 2007]. All of these factors could account for species within each of our graptolite biotopes having a wide latitudinal range.

[32] The paleolatitudinal ranges of our graptolite biotopes correspond broadly to the paleolatitudes predicted in the hypothetical zooplankton models for $\mathrm{x} 8$ and $\mathrm{x} 15 \mathrm{PAL}$ $p \mathrm{CO}_{2}$; that is, graptolite biotope boundaries are broadly coincident with the predicted boundaries of the modern planktonic foraminiferal provinces based on modeled Ordovician SSTs (Figure 9). This is a fundamental observation as it indicates that our graptolite biotopes are true ecological entities, comparable to modern zooplankton 
provinces and thus through analogy can be used to interpret the primary ecological controls on graptolites.

[33] In the $\mathrm{x} 8 p \mathrm{CO}_{2}$ zooplankton model the Tropical and Subtropical Provinces are distributed as at the present day, but the Transitional province has a much narrower latitudinal range, apparently contracting to accommodate a broader Subpolar Province (Figure 9c). In the $\mathrm{x} 15 \mathrm{pCO}_{2}$ zooplankton model, the Tropical and Subpolar Provinces are much broader than at present day, and the Subtropical and Transitional provinces are slightly restricted. The Polar Province ranges to $\sim 70^{\circ} \mathrm{S}$ (Figure $9 \mathrm{~b}$ ).

[34] In the $\mathrm{x} 8 \mathrm{pCO}_{2}$ zooplankton model, Biotopes $\mathrm{C} 1$ and C2 (and the D1 and D2 biotopes) coincide with the Tropical Province, C3 and D3 can be either tropical or subtropical and C4 (and D4/D5) coincide with the Subtropical Province. Species characteristic of Biotope A were largely restricted to south of $\sim 35^{\circ} \mathrm{S}$, indicative of cooler water and coincident with the Transitional to Polar Provinces in the zooplankton model (Figure 9). Interestingly, cooler water biotope A spreads to a rather equatorward position $\left(\sim 35^{\circ} \mathrm{S}\right)$, but it is characterized by a single species and may reflect (1) local or (2) current-driven phenomena (see below), and further work is required to establish the fidelity of this province. Biotopes $\mathrm{C} 5, \mathrm{C} 6$ and $\mathrm{C} 7$ lie within the latitudinal range of Biotope $\mathrm{A}$, but remain distinct in the analysis. Biotope $\mathrm{C} 5$ coincides with the predicted position of the Transitional Zone within the hypothetical zooplankton model. Biotopes C6 and C7 coincide with Subpolar and Polar waters, respectively. It is likely that because of the lower sampling densities on high-latitude Gondwana, we may only be recording a small part of a much wider distribution for these biotopes.

[35] Similar attributions can be made for the low-latitude graptolite biotopes in the $\mathrm{x} 15 \mathrm{pCO}_{2}$ hypothetical zooplankton model, but biotope C3/D3 is Tropical, C4 (and D4/D5) can be either Tropical or Subtropical, C6 is now part of the Transition zone and C7 falls in the Subpolar waters.

[36] However, a more robust signal than the attribution of the graptolite biotopes to a specific climate belt or province, is the observation that the faunal gradient from equator to pole displayed in the graptolites of the gracilis time slice is steep, and comparable to that of modern-day zooplankton. This is in contrast with the hypothesized greenhouse state for this time interval. The observed faunal gradient in the graptolites is much steeper than that of zooplankton in warmer periods of Earth history (Figure 9e), such as that of the planktonic foraminifera provinces of the latest Albian [Hart, 2007], a known greenhouse world.

[37] Biotope C1 (incorporating mainly widespread species), and also biotope $\mathrm{A}$, have similar latitudinal distributions to those modeled for the currents that formed part of the "South Panthalassic convergence" gyre and the South Gondwana Current, respectively [Wilde, 1991; Poussart et al., 1999; Herrmann et al., 2004] and we speculate that these biotopes may have been restricted to surface waters associated with these current systems (Figure 1). The boundary between warm, equatorial and cold, Gondwanaderived surface waters occurs at $\sim 40^{\circ} \mathrm{S}$ and defines the position of the convergence zone between the South
Panthalassic convergence gyre and the South Gondwana Current in the SST simulation (Figure 1).

[38] In summary, we propose that during the gracilis time slice, the zooplankton gradient as derived from graptolite distribution data was steep and not unlike that of modern zooplankton and the latitudinal extent of the tropics and subtropics was similar to the present day. This suggests a nongreenhouse state for the climate-ocean system during the gracilis time slice and would imply that a cool world (if not a full icehouse world) was established by the early Late Ordovician, i.e., much earlier than has been previously hypothesized. Paradoxically a nongreenhouse state during the early Late Ordovician occurred despite relatively high atmospheric $\mathrm{pCO}_{2}$. Our graptolite distribution data are consistent with the stabilization of the climate to a modern configuration [Trotter et al., 2008]. The suggested coincidence of a nongreenhouse state with high sea levels [cf. Webby et al., 2004a] is unexpected and requires further investigation.

\section{Conclusions}

[39] 1. TWINSPAN analysis and constrained seriation provide robust groupings reflecting ecological structure in presence/absence data of graptolites.

[40] 2. The highest-level groups reflect tropical-subtropical assemblages and a high-latitude assemblage. Constrained seriation defines latitudinally distinct biotopes within these assemblages that are considered equivalent to the modern zooplanktonic provinces.

[41] 3. TWINSPAN groups $\mathrm{C}$ and $\mathrm{D}$ (that would have been attributed to the "epipelagic biotope" and "deep water biotope" in the sense of Cooper et al. [1991], respectively) have the same latitudinal distribution and hence SST control; this suggests that species from both groups lived at similar shallow depths but that the water masses they inhabited were laterally differentiated. Our results are therefore consistent with the lateral differentiation model for graptolite paleoecology [e.g., Finney and Berry, 1997].

[42] 4. The distribution pattern of graptolite biotopes in the gracilis time slice supports the OGCM climate simulations proposed by Herrmann et al. [2004] with, (1) high relative sea levels and, (2) elevated atmospheric $p \mathrm{CO}_{2}$ levels boundary conditions.

[43] 5. Graptolite biotopes display a steep equator-to-pole faunal gradient that is not unlike the present day and that is indicative of a cooler world than previously hypothesized for the early Late Ordovician; this supports the climate stabilization hypothesis of Trotter et al. [2008]. Paradoxically the climate of the early Late Ordovician was in many respects similar to that of the present day despite the much higher atmospheric $p \mathrm{CO}_{2}$ levels.

[44] 6. Some graptolites may have been restricted to surface currents. Computer models proposed by Wilde [1991], Poussart et al. [1999] and Herrmann et al. [2004] show similar surface current patterns in the Southern Hemisphere in the Mid-Late Ordovician to the present day. Surface graptolite distribution patterns seem to support this, as species within biotope $\mathrm{C} 1$ are most likely to be transported 
Table A1. Species Attributed to Each Biotope and/or TWINSPAN Group

\begin{tabular}{|c|c|}
\hline TWINSPAN Group & Species \\
\hline A & Climacograptus brevis mutabilis, Orthograptus uplandicus and Oepikograptus bekkeri \\
\hline B & Dicellograptus divaricatus salopiensis, Diplograptus molestus \\
\hline \multicolumn{2}{|r|}{ 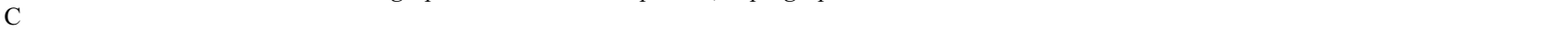 } \\
\hline $\mathrm{C} 1$ & $\begin{array}{l}\text { Corynoides serpens, Dicellograptus divaricatus rigidus, Dicellograptus moffatensis alabamensis, } \\
\text { Dicranograptus nicholsoni longibasalis, Glossograptus armatus, Orthograptus calcaratus calcaratus, } \\
\text { Cryptograptus tricornis schaeferi, Cryptograptus tricornis tricornis, Dicellograptus divaricatus divaricatus, } \\
\text { Dicellograptus intortus, Dicellograptus sextans sextans, Dicranograptus irregularis, Nemagraptus gracilis gracilis, } \\
\text { Normalograptus brevis, Acrograptus superstes, Amplexograptus arctus, Climacograptus antiquus antiquus, } \\
\text { Climacograptus bicornis bicornis, Dicranograptus nicholsoni nicholsoni, Glossograptus hincksii fimbriatus, } \\
\text { Glossograptus hincksii hincksii, Lasiograptus harknessi costatus, Normalograptus euglyphus euglyphus, } \\
\text { Pseudoclimacograptus scharenbergi scharenbergi, Reteograptus geinitzianus }\end{array}$ \\
\hline $\mathrm{C} 2$ & $\begin{array}{l}\text { Dicranograptus ziczac, Thamnograptus capillaris, Hallograptus bimucronatus, Archiclimacograptus modestus, } \\
\text { Dicranograptus rectus, Hustedograptus teretiusculus, Orthograptus quadrimucronatus whitfieldi, } \\
\text { Amplexograptus perexcavatus, Corynoides curtus curtus, Lasiograptus pusillus }\end{array}$ \\
\hline $\mathrm{C} 3$ & $\begin{array}{l}\text { Dicranograptus cyathiformis, Dicranograptus tardiusculus, Diplograptus compactus, Hallograptus mucronatus nobilis, } \\
\text { Leptograptus ascendens, Nemagraptus pertenuis, Thamnograptus scoticus, Dicranograptus celticus, } \\
\text { Dicellograptus patulosus, Leptograptus validus incisus, Lasiograptus harknessi harknessi, } \\
\text { Leptograptus flaccidus flaccidus, Leptograptus grandis, Diplograptus notabilis, Climacograptus antiquus lineatus, } \\
\text { Dicellograptus geniculatus, Dicranograptus brevicaulis, Diplograptus foliaceus, Diplograptus leptotheca, } \\
\text { Leptograptus validus validus, Nemagraptus subtilis, Orthograptus apiculatus, Dicranograptus furcatus minimus }\end{array}$ \\
\hline $\mathrm{C} 4$ & Corynoides curtus pristinus, Dicellograptus cambriensis, Ensigraptus caudatus, Haddingograptus eurystoma \\
\hline $\mathrm{C} 5$ & $\begin{array}{l}\text { Dicranograptus kirki, Dicranograptus spiniferus, Leptograptus flaccidus macer, } \\
\text { Nanograptus phylloides, Normalograptus kuckersianus }\end{array}$ \\
\hline C6 & $\begin{array}{l}\text { Amplexograptus rugosus, Azygograptus mobergi, Climacograptus haddingi, Climacograptus putillus (Hadding non Hall), } \\
\text { Dicellograptus pumilus, Diplograptus propinquus, Diplograptus toernquisti, Glossograptus scanicus, } \\
\text { Janograptus laxatus, Lasiograptus spinatus Hadding, Nemagraptus gracilis remotus, } \\
\text { Nanograptus lapworthi, Normalograptus minimus }\end{array}$ \\
\hline $\mathrm{C} 7$ & Archiclimacograptus caelatus, Climacograptus cf. putillus (Hall), Climacograptus sheldoni, Didymograptus euodus \\
\hline \multicolumn{2}{|r|}{ (1) } \\
\hline D1 & $\begin{array}{l}\text { Climacograptus brevis strictus, Climacograptus cruciformis, Corynoides australis, Glossograptus acanthus, } \\
\text { Glossograptus ovatus, Lasiograptus asiaticus, Nicholsonograptus fasciculatus, Orthograptus expansus, } \\
\text { Paraglossograptus tentaculatus, Pseudoclimacograptus scharenbergi angulatus, Reteograptus speciosus, } \\
\text { Pseudoclimacograptus riddellensis, Archiclimacograptus stenostoma, Azygograptus incurvus, Dicellograptus } \\
\text { bispiralis bispiralis, Kalpinograptus lyra, Dicranograptus furcatus, Dicranograptus ramosus longicaulis, } \\
\text { Dicellograptus gurleyi gurleyi, Leptograptus flaccidus trentonensis, Climacograptus bicornis tridentatus, } \\
\text { Corynoides calicularis, Orthograptus calcaratus vulgatus, Dicellograptus sextans exilis, Dicranograptus } \\
\text { ramosus ramosus, Dicranograptus ramosus spinifer, Glossograptus ciliatus ciliatus, Hallograptus } \\
\text { mucronatus mucronatus, Orthograptus calcaratus acutus }\end{array}$ \\
\hline $\mathrm{D} 2$ & $\begin{array}{l}\text { Climacograptus spiniferus, Dicranograptus nicholsoni whitianus, Trigonograptus martelii, Dicranograptus } \\
\text { nicholsoni geniculatus, Glossograptus horridus, Neurograptus margaritatus, Orthograptus calcaratus } \\
\text { basilicus, Climacograptus bicornis peltifer, Climacograptus eximius, Dicellograptus divaricatus } \\
\text { bicurvatus, Dicellograptus smithi, Dicranograptus contortus, Didymograptus serratulus, Diplograptus } \\
\text { multidens var. diminutus, Nemagraptus exilis exilis, Nemagraptus exilis linearis, Nemagraptus gracilis } \\
\text { var. surcularis, Normalograptus euglyphus pygmaeus, Orthograptus calcaratus incisus, Diplograptus } \\
\text { multidens multidens, Corynoides incurvus }\end{array}$ \\
\hline D3 & $\begin{array}{l}\text { Orthograptus calcaratus alabamensis, Climacograptus modestus meridionalis, Dicellograptus gurleyi exilis, } \\
\text { Dicranograptus nicholsoni parvangulus, Didymograptus subtenuis, Corynoides tricornis }\end{array}$ \\
\hline D4 & Amphigraptus divergens, Climacograptus parvus, Didymograptus sagitticaulis, Dicellograptus sextans var. perexilis \\
\hline D5 & $\begin{array}{l}\text { Orthograptus truncatus truncatus, Azygograptus simplex, Climacograptus phyllophorus, Corynoides americanus, } \\
\text { Cryptograptus marcidus, Dicellograptus divaricatus rectus, Dicellograptus mensurans, Dicranograptus clingani, } \\
\text { Dicranograptus furcatus exilis, Dicranograptus nicholsoni diapason, Dicranograptus spinifer geniculatus, } \\
\text { Glossograptus ciliatus var. debilis, Nemagraptus linmassiae, Pseudoclimacograptus angulatus angulatus }\end{array}$ \\
\hline
\end{tabular}

toward the South Pole and across latitudes by currents associated with the South Panthalassic convergence gyre.

[45] 7. The latitudinal distribution of graptolite biotopes reflects temperature-controlled climate zones. Graptolites are therefore water mass-specific and so can be used to track changes in the climate system and to ground-truth Early Paleozoic climate models, much in a way that the zooplankton has been applied in climate modeling in the Cenozoic.

\section{Appendix A: Species Attributed to Each Biotope and/or TWINSPAN Group}

[46] TWINSPAN analysis divides the graptolite fauna into four groups $(\mathrm{A}-\mathrm{D})$. Further subdivisions of the TWIN-
SPAN groups by constrained seriation create a number biotopes $(\mathrm{C} 1-\mathrm{C} 7$ and $\mathrm{D} 1-\mathrm{D} 5)$. In Table A1 we present the full species lists for each TWINSPAN group and biotope.

[47] Acknowledgments. Harry Dowsett provided a constructive review that greatly improved this paper. We acknowledge the fruitful discussions we have had with many colleagues but particularly Ulrich Saltzman, Mark Chandler, Linda Sohl, Barrie Rickards, Adrian Rushton, Daniel Goldman, Jörg Maletz, Kenneth Mertens, Jacques Verniers, Stephen Louwye, Tom Challands, Charles Wilson, David Harper, Andrea Snelling, Mike Howe, Richard Fortey, Jaak Nolvak, Florentin Paris, Alex Page, and Ben Wood who have greatly influenced our ideas and willingly provided data and literature sources for this study. This research was funded by the Research Foundation-Flanders. This is a contribution to the IGCP 503. 


\section{References}

Armstrong, H. A. (2007), On the cause of the Ordovician glaciation, in Deep-Time Perspectives on Climate Change: Marrying the Signal From Computer Models and Biological Proxies, edited by M. Williams et al., pp. 101-121, Geol. Soc., London.

Armstrong, H. A., and M. Brasier (2005), Microfossils, 304 pp., Blackwell, Oxford, U. K.

Bengtson, P. (1988), Open nomenclature, Palaeontology, 32(1), 223-227.

Bergström, S. M. (1983), Biogeography, evolutionary relationships, and biostratigraphic significance of Ordovician platform conodonts, Fossils Strata, 15, 35-58.

Bergström, S. M., S. C. Finney, C. Xu, and Z.-H. Wang (1998), The base of the Nemagraptus gracilis zone as the base of the global Upper Ordovician series: Three potential stratotypes, in Proceedings of the Sixth International Graptolite Conference of the GWG (IPA) and the SW Iberia Field Meeting 1998 of the International Subcommission on Silurian Stratigraphy (ICS-IUGS), Temas Geol. Miner, vol. 23, edited by J. C. Gutierrez-Marco and I. Rabano, pp. 148-151, Inst. Tecnol. Geominero de Esp., Madrid.

Bergström, S. M., S. C. Finney, C. Xu, C. Pålsson, Z.-H. Wang, and Y. Grahn (2000), A proposed global boundary stratotype for the base of the upper series of the Ordovician system: The Fågelsång section, Scania, southern Sweden, Episodes, 23(2), 102-109.

Cifelli, R., and C. Stern Benier (1976), Planktonic foraminifera from near the West African coast and a consideration of faunal parcelling in the North Atlantic, J. Foraminiferal Res., 6(4), 258-273.

Cocks, L. R. M., and T. H. Torsvik (2004), Major terranes in the Ordovician, in The Great Ordovician Biodiversification Event, edited by B. D. Webby et al., chap. 5, pp. 61-67, Columbia Univ. Press, New York.

Cooper, R. A. (1998), Towards a general model for the depth ecology of graptolites, in Proceedings of the Sixth International Graptolite Conference of the GWG (IPA) and the SW Iberia Field Meeting 1998 of the International Subcommission on Silurian Stratigraphy (ICSIUGS), Temas Geol. Miner, vol. 23, edited by J. C. Gutierrez-Marco and I. Rabano, pp. 161163, Inst. Tecnol. Geominero de Esp., Madrid.

Cooper, R. A., and P. M. Sadler (2004), The Ordovician period, in A Geological Time Scale 2004, edited by F. M. Gradstein, J. G. Ogg, and A. G. Smith, chap. 12, pp. 165-187, Cambridge Univ. Press, Cambridge, U. K.

Cooper, R. A., R. A. Fortey, and K. Lindholm (1991), Latitudinal and depth zonation of Early Ordovician graptolites, Lethaia, 24, 199-218, doi:10.1111/j.1502-3931.1991.tb01468.x.

Dowsett, H. J. (2007), The PRISM palaeoclimate reconstruction and Pliocene sea-surface temperature, in Deep-Time Perspectives on Climate Change: Marrying the Signal From Computer Models and Biological Proxies, edited by M. Williams et al., pp. 459-480, Geol. Soc., London.

Elles, G. L. (1925), The characteristic assemblages of the graptolite zones of the British Isles, Geol. Mag., 62, 337-347, doi:10.1017/ S0016756800105813.

Finney, S. C. (1984), Biogeography of Ordovician graptolites in the southern Appalachians, in Aspects of the Ordovician System, edited by D. L. Bruton, pp. 167-176, Univ. of Oslo, Paleontol. Mus., Oslo, Norway.
Finney, S. C. (1986), Graptolite biofacies and correlation of eustatic, subsidence, and tectonic events in the Middle to Upper Ordovician of North America, Palaios, 1, 435-461, doi: $10.2307 / 3514628$.

Finney, S. C., and S. M. Bergström (1986), Biostratigraphy of the Ordovician Nemagraptus gracilis zone, in Palaeoecology and Biostratigraphy of Graptolites, edited by C. P. Hughes and R. B. Rickards, Spec. Publ. Geol. Soc., 20, 47-59.

Finney, S. C., and W. B. N. Berry (1997), New perspectives on graptolite distributions and their use as indicators of platform margin dynamics, Geology, 25(10), 919-922, doi:10.1130/00917613(1997)025<0919:NPOGDA $>2.3$.CO;2.

Finney, S. C., W. B. N. Berry, and J. D. Cooper (2007), The influence of denitrifying seawater on graptolite extinction and diversification during the Hirnantian (Latest Ordovician) mass extinction event, Lethaia, 40, 281-291.

Gradstein, F. M., J. G. Ogg, and A. G. Smith (2004), A Geological Timescale 2004, 610 pp., Cambridge Univ. Press, Cambridge, U. K.

Gutiérrez-Marco, J. C., I. Rábano, M. A. San José, P. Herranz, and G. N. Sarmiento (1995), Oretanian and Dobrotivian stages vs. "LlanvirnLlandeilo" series in the Ordovician of the Iberian Peninsula, in Ordovician Odyssey: Short Papers for the 7th ISOS in Las Vegas, edited by J. D. Cooper, M. L. Droser, and S. C. Finney, pp. 55-59, Soc. for Sediment. Geol. Pac. Sect., Fullerton, Calif.

Hammer, O., and D. A. T. Harper (2006), Paleontological Data Analysis, 368 pp. Blackwell, Oxford, U. K.

Hart, M. B. (2007), Late Cretaceous climates and foraminiferid distributions, in Deep-Time Perspectives on Climate Change: Marrying the Signal From Computer Models and Biological Proxies, edited by M. Williams et al., pp. 235250, Geol. Soc., London.

Hede, J. E. (1951), Boring through Middle Ordovician-Upper Cambrian strata in the Fågelsång district, Scania (Sweden), Lunds Univ. Arsskr., 7, 1-84.

Herrmann, A. D., B. J. Haupt, M. E. Patzkowsky, D. Seidov, and R. L. Slingerland (2004), Response of Late Ordovician paleoceanography to changes in sea level, continental drift, and atmospheric $p \mathrm{CO}_{2}$ : Potential causes for longterm cooling and glaciation, Palaeogeogr Palaeoclimatol. Palaeoecol., 210, 385-401, doi:10.1016/j.palaeo.2004.02.034.

Hill, M. O. (1979), TWINSPAN: A FORTRAN Program for Arranging Multivariate Data in an Ordered Two-Way Table by Classification of Individuals and Attributes, 90 pp., Cornell Univ., Ithaca, N. Y.

Hughes, R. A. (1989), Llandeilo and Caradoc Graptolites of the Builth and Shelve Inliers, Monogr. Palaeontogr. Soc., vol. 577, 89 pp., Palaeontogr. Soc., London.

Kucera, M. (2007), Planktonic foraminifera as tracers of past oceanic environments, in Developments in Marine Geology, vol. 1, Proxies in Late Cenozoic Paleoceanography, edited by C. Hillaire-Marcel and A. de Vernal, pp. 213 262, Elsevier, Amsterdam.

Lincoln, R., G. Boxshall, and P. Clark (1998), A Dictionary of Ecology, Evolution and Systematics, 2nd ed., 361 pp., Cambridge Univ. Press, Cambridge, U. K

Locarnini, R. A., A. V. Mishonov, J. I. Antonov, T. P. Boyer, and H. E. Garcia (2006), World Ocean Atlas 2005, vol. 1, Temperature, NOAA
Atlas NESDIS, vol. 61, edited by S. Levitus, 182 pp., NOAA, Silver Spring, Md.

Nõlvak, J., and Y. Grahn (1993), Ordovician chitinozoan zones from Baltoscandia, Rev Palaeobot. Palynol., 79, 245-269, doi:10. 1016/0034-6667(93)90025-P.

Page, A. A., J. A. Zalasiewicz, M. Williams, and L. E. Popov (2007), Were transgressive black shales a negative feedback modulating glacioeustasy in the early Palaeozoic icehouse? in Deep-Time Perspectives on Climate Change: Marrying the Signal From Computer Models and Biological Proxies, edited by M. Williams et al., pp. 123-156, Geol. Soc. London.

Paris, F. (1990), The Ordovician chitinozoan biozones of the northern Gondwana domain, Rev Palaeobot. Palynol., 66, 181-209, doi:10. 1016/0034-6667(90)90038-K.

Poussart, P. F., A. J. Weaver, and C. R. Barnes (1999), Late Ordovician glaciation under high atmospheric $\mathrm{CO}_{2}$ : A coupled model analysis, Paleoceanography, 14(4), 542-558, doi:10.1029/1999PA900021.

Raymont, J. E. G. (1983), Plankton and Productivity in the Oceans, vol. 2, Zooplankton, Pergamon, Southampton, U. K.

Saltzman, M. R., and S. A. Young (2005), Longlived glaciation in the Late Ordovician? Isotopic and sequence-stratigraphic evidence from western Laurentia, Geology, 33(2), 109-112, doi:10.1130/G21219.1

Schrag, D. P., D. J. DePaolo, and F. M. Richter (1995), Reconstructing past sea surface temperatures: Correcting for diagenesis of bulk marine carbonate, Geochim Cosmochim. Acta, 59(11), 2265-2278, doi:10.1016/ 0016-7037(95)00105-9.

Scotese, C. R., and W. S. McKerrow (1990), Revised world maps and introduction, in Palaeozoic Palaeogeography and Biogeography, edited by W. S. McKerrow and C. R. Scotese, Mem. Geol. Soc. London, 12, 1-21.

Shields, G. A., G. A. F. Carden, J. Veizer, T. Meidla, J.-Y. Ronga, and R.-Y. Li (2003), $\mathrm{Sr}, \mathrm{C}$, and $\mathrm{O}$ isotope geochemistry of Ordovician brachiopods: A major isotopic event around the Middle-Late Ordovician transition, Geochim. Cosmochim. Acta, 67(11), 20052025, doi:10.1016/S0016-7037(02)01116-X.

Skevington, D. (1974), Controls influencing the composition and distribution of Ordovician graptolite faunal provinces, Spec. Pap. Palaeontol. $13,59-73$

Sonzogni, C., E. Barda, and F. Rosteka (1998), Tropical sea-surface temperatures during the last glacial period: A view based on alkenones in Indian Ocean sediments, Ouat. Sci. Rev. 17(12), 1185-1201, doi:10.1016/S02773791(97)00099-1.

Tobin, K. J., and S. M. Bergström (2002), Implications of Ordovician $(\approx 460 \mathrm{Myr})$ marine cement for constraining seawater temperature and atmospheric $p \mathrm{CO}_{2}$, Palaeogeogr. Palaeoclimatol. Palaeoecol., 181, 399-417, doi:10. 1016/S0031-0182(01)00436-9.

Trotter, J. A., I. S. Williams, C. R. Barnes, C. Lécuyer, and R. S. Nicoll (2008), Did cooling oceans trigger Ordovician biodiversification? Evidence from conodont thermometry, Science, 321(5888), 550-554, doi:10.1126 science. 1155814

Vandenberg, A. H. M., and R. A. Cooper (1992), The Ordovician graptolite sequence of Australasia, Alcheringa, 16, 33-85, doi:10.1080/ 03115519208619032. 
Vandenbroucke, T. R. A. (2004), Chitinozoan biostratigraphy of the Upper Ordovician Fågelsång section, Scania, southern Sweden, Rev. Palaeobot. Palynol., 130, 217-238, doi:10.1016/j.revpalbo.2003.12.008.

Webby, B. D., M. L. Droser, F. Paris, and I. Percival (2004a), The Great Ordovician Biodiversification Event, 484 pp., Columbia Univ. Press, New York.

Webby, B. D., R. A. Cooper, S. M. Bergström, and F. Paris (2004b), Stratigraphic framework and time slices, in The Great Ordovician Biodiversification Event, edited by B. D. Webby et al., chap. 2, pp. 41-47, Columbia Univ. Press, New York.

Wilde, P. (1991), Oceanography in the Ordovician, in Advances in Ordovician Geology, edited by C. R Barnes and S. H. Williams, Pap. Geol. Surv. Can., 90-9, 225-234.
Williams, M., J. R. Davies, R. A. Waters, A. W. A. Rushton, and P. R. Wilby (2003), Stratigraphical and palaeoecological importance of Caradoc (Upper Ordovician) graptolites from the Cardigan area, southwest Wales, Geol. Mag., 140, 549-571, doi:10.1017/S0016756803008057.

Williams, M., A. W. A. Rushton, B. Wood, J. D. Floyd, R. Smith, and C. Wheatley (2004), A revised graptolite biostratigraphy for the lowe Caradoc (Upper Ordovician) of southern Scotland, Scott. J. Geol., 40(2), 97-114.

Zachos, J. C., G. R. Dickens, and R. E. Zeebe (2008), An early Cenozoic perspective on greenhouse warming and carbon-cycle dynamics, Nature, 451(7176), 279-283, doi:10.1038/nature06588.

Zalasiewicz, J. A., L. Taylor, A. W. A. Rushton, D. K. Loydell, R. B. Rickards, and M. Williams
(2009), Graptolites in British stratigraphy, Geol. Mag., doi:10.1017/S0016756809990434, in press.

H. A. Armstrong, Palaeozoic Environments Group, Department of Earth Sciences, Durham University, Durham DH1 3LE, UK.

K. Sabbe, Protistology and Aquatic Ecology, Department of Biology, Ghent University, WE11-S8, B-9000 Ghent, Belgium.

T. R. A. Vandenbroucke, Research FoundationFlanders, Research Unit Palaeontology, Department of Geology and Soil Sciences, Ghent University, WE13-S8, B-9000 Ghent, Belgium. (thijs.vandenbroucke@ugent.be)

M. Williams and J. A. Zalasiewicz, Department of Geology, University of Leicester, Leicester LE1 7RH, UK. 